\title{
The impact of broadband and other infrastructure on the location of
} new business establishments

\author{
Daire $\mathrm{McCoy}^{1}{ }^{2 *}$, Sean Lyons $^{2},{ }^{3}$, Edgar Morgenroth ${ }^{2},{ }^{3}$, Donal Palcic ${ }^{4}$ \\ Leonie Allen ${ }^{5}$ \\ ${ }^{1}$ Grantham Research Institute, London School of Economics, UK \\ ${ }^{2}$ The Economic and Social Research Institute, Ireland \\ ${ }^{3}$ Department of Economics, Trinity College Dublin, Ireland \\ ${ }^{4}$ University of Limerick, Ireland \\ ${ }^{5}$ The Commission for Communication Regulation (ComReg), Ireland
}

November 17, 2017

\begin{abstract}
This paper analyses the impact of broadband infrastructure, along with a range of other local characteristics such as motorways and other infrastructure, availability of human capital and access to third level educational facilities, on the location of new business establishments. The sample period spans the introduction and recent history of broadband in Ireland. The results indicate that the availability of broadband infrastructure is a significant determinant, but its effects may be mediated by the presence of sufficiently high human capital in an area.
\end{abstract}

Keywords: New business establishments; ICT; Infrastructure; Count panel regression model

JEL Classification: R3; R11; D22

\section{Acknowledgements}

This work makes use of data from the Annual Employment Survey conducted by the Department of Jobs, Enterprise and Innovation. We would like to thank Dr. Jonathan Healy in particular, for granting access and

*Corresponding author. Tel:+44 7716150581 E-mail address: d.m.mccoy@lse.ac.uk 
facilitating usage of the data. We are also grateful to several private companies for providing data and helpful assistance. These include enet, Eircom/Eir, BT and ESB Networks. We are grateful for financial support for this research from the Department of Communications, Energy and Natural Resources, ComReg and Science Foundation Ireland under grant No.09/SRC/E1780. We also acknowledge funding from the Grantham Research Institute on Climate Change and the Environment. We thank seminar participants for useful comments at the ESRI; the Department of Economics in NUI Galway; DJEI; UCD ERC; The Regional Studies Association, Irish Branch Annual Conference, UCC September 2015; The Regional Studies Association Winter Conference, London, November 2015; European Regional Science Association Congress, Vienna 2016; The Regional Science Association, British and Irish Section, Annual Conference, Newquay 2016. All views expressed and any errors are of course the authors' own. Any views expressed are not attributable to the Commission for Communications Regulation. 


\section{Introduction}

A key determinant of the economic performance of regions is the rate of new enterprise formation. This is arguably a better indicator of a region's future development than current employment levels, since newly locating plants respond to current incentives, whereas current employment levels depend primarily on prior location decisions (Carlton, 1983).

Recent work has explored the diffusion of information and communications technology (ICT) infrastructure as a factor in explaining regional variation in a range of economic outcomes, including new firm formation and local growth (Mack and Grubesic, 2009; Kolko, 2012).

Other research has shown that the productivity effects of ICT can depend on complementary effects with other inputs, such as the availability of skilled labour, and how the ICT is actually used (David et al., 2003; Mack and Faggian, 2013). ICT can displace less technically advanced workers while enabling higher skilled workers to be more productive. Thus ICT investment may be either a substitute or complement to labour, and correspondingly may have different productivity effects depending upon the skill mix prevalent in a given sector or area (Akerman et al., 2015; Hidalgo Perez et al., 2016), or whether firms can adapt their business practices appropriately (Colombo et al., 2013).

Given these relationships must also be observed internally by firms, one might expect entrepreneurs and firms to incorporate them in their location decisions. Areas with pre-existing high levels of human capital and knowledge intensive firms may be better equipped to reap the rewards of broadband roll-out than other areas less endowed with these attributes. Further, the uneven nature of broadband roll-out in time and space might result in sub-optimal deployment patterns. A number of studies have found this to be the case, and that the positive impact of broadband across a range of economic outcomes is more pronounced in urban areas and for knowledge-intensive firms (Gillet et al., 2006; Kandilov and Renkow, 2010; Mack and Faggian, 2013) ${ }^{1}$. For urban areas the effect can depend on area size and industrial legacy (Mack and Rey, 2014). Firm size and industry type have also been found to affect the relationship between broadband and new business establishments (Mack and Grubesic, 2009).

We extend this work, by examining how the impact of broadband roll-out on the location of new firms depends on the existing skill-level in an area. The factors influencing the location of new business establishments are examined with a particular focus on the roll-out of basic broadband and it's interaction with human capital, measured as the level of educational attainment in each area. A unique panel-dataset of traditional digital subscriber line (DSL) and middle-mile fibre-broadband networks is created, allowing an examination of the relative impact of each on different types of firm. Our analysis focuses on regional towns and cities, and rural

\footnotetext{
${ }^{1}$ Even within rural areas the positive effects are more pronounced in those adjacent to urban areas and with greater populations (Kim and Orazem, 2017)
} 
areas. We omit the most populated and least populated areas as these are qualitatively different from all other locations in the sample choice set.

Firm formation is affected by a range of other factors, such as clustering (Armington and Acs, 2002), agglomeration (Devereux et al., 2007; Alañón-Pardo and Arauzo-Carod, 2013) and specialisation (Feldman and Audretsch, 1999). Transport infrastructure also matters (Button et al., 1995; Holl, 2004a,b; Percoco, 2015), and proximity to universities is particularly important for knowledge-intensive firms (Zucker et al., 1998; Audretsch et al., 2005). However, empirical research in this area has tended to focus on a subset of factors only, which increases the possibility of omitted variable bias. A recent exception is Audretsch et al. (2015) who examine the link between infrastructure and the startup activity of new firms at the county level across Germany over the period 2001-2005. Specifically the authors test for the relationship between new firm formation and the availability of broadband, motorway and rail infrastructure along with the presence of a university or research institution. Broadband was found to have a greater impact on startup activity than other forms of infrastructure, particularly in sectors such as software.

Our analysis builds on the work of Audretsch et al. (2015) and addresses the shortcomings of previous studies that focus on a limited range of factors that influence new firm formation by including a more comprehensive set of control variables. To this end the ICT data is supplemented with a broader set of infrastructure measures than has previously been examined in this literature. This includes proximity to motorways, universities and other third-level institutions, airports and rail stations ${ }^{2}$. This information is combined with other important firm location determinants such as agglomeration economies, specialisation, human capital and data on the relative cost and quality of the labour force.

Another shortcoming in the existing literature is that the data available usually only covers a relatively short period, with a limited amount of space-time variation in the key variables. This makes identification of effects more difficult. The sample period for our dataset encompasses a period when Ireland's infrastructure was rapidly improved. For example the DSL roll-out data spans 0-100\% penetration over our sample period, with substantial local variation. This is combined with GIS information on a national middle-mile fibre-optic network roll-out ${ }^{3}$ including detailed information on the characteristics of these networks, and when they became operational. This allows an examination of the period in which broadband was introduced in Ireland, and compared with previous work is a significant improvement in broadband data quality.

Another feature of the sample period is that $86 \%$ of the current motorway network was constructed and average drive times to the nearest motorway junction almost halved. To capture a similar degree of space-

\footnotetext{
${ }^{2}$ Various papers have considered the effects of different transport structures. For example Boarnet (1998) analyzed the spillover effects of motorway development, and in a recent paper Garcia-López et al. (2017) show that proximity to railways stations has had a significant impact on the spatial pattern of employment and population growth in Greater Paris.

${ }^{3}$ The Metropolitan Area Networks, or "MANs"
} 
time variation in the development of the motorway network in other developed countries would require data over a sample period of 40 years or more in many cases (see Figure 2). In addition, unlike much of the empirical literature, detailed spatial and temporal information on the drive-time to every motorway junction from the centroid of each location is used. Including the drive-time, rather than distance allows us to account for underlying road quality.

New firm formation in each area over time is modelled with negative-binomial (NB) panel estimators and a unit of analysis which helps to account for excess zeros and spatial dependence is used. These factors are also explicitly controlled for in robustness tests. It has been argued that focusing on new firm formation, rather than growth or other economic outcomes reduces problems of reverse causality between these measures and agglomeration economies or labour market factors (Jofre-Monseny et al., 2011; Artz et al., 2015). A range of specifications with lagged independent variables are estimated to further reduce reverse causality. An endogenous relationship may also exist between firm location choices and the placement of broadband infrastructure. To account for this, plausibly exogenous variation in MAN roll-out is exploited ${ }^{4}$, and fixed effects for each MAN location are included to control for any time-invariant unobserved factors which might attract both firms and broadband. As the period in question was a turbulent one in Ireland's recent economic history, year fixed effects are also included to absorb any broader macroeconomic trends which might impact new firm formation.

Results show that both initial DSL and middle-mile fibre broadband have had a positive impact on firm formation, particularly in the high-tech sectors. Previous work has pointed to a skill complementarity between broadband adoption and skilled-labour. The results of this research indicate that pre-existing levels of human capital appear to be an important indicator of an area's ability to absorb new ICT technologies productively, in the form of new business establishments. The results also suggest a non-linear relationship in the effect of broadband along the distribution of educational attainment. The effect is greater for areas with greater education levels and may not be significantly different from zero below a threshold level of local educational attainment.

The rest of the paper is organised as follows; the following section describes the methodological approach and considerations undertaken; Section 2.3 the data; Section 3 outlines the empirical results; Section 4 outlines the robustness measures undertaken and Section 6 concludes.

\footnotetext{
${ }^{4}$ These networks were rolled-out to most towns and cities with a population of 1,500 or above. For details see http://www.dcenr.gov.ie/communications/en-ie/Broadband/Pages/Metroplian-Area-Networks.aspx
} 


\section{Empirical approach and data}

\section{$2.1 \quad$ The model}

The literature suggests that for both foreign and domestic new business establishments, the attractiveness of an area should be a function of agglomerative forces, factors relating to human capital, labour market pooling and relative labour costs. Infrastructure provision and market access should also play an important role. Demand based factors should matter more for domestic firms, as foreign firms locating in Ireland largely use it as an export platform.

Within the business establishment literature, two main methodologies are employed; choice models or count models $^{5}$. We implement a count framework as we have a large proportion of zeros in our dependent variables and a relatively large choice set. New firm counts in a particular area in each time period are modelled as function of area characteristics, with year fixed-effects and sector-type effects included also, for sector-specific regressions.

Formally:

$$
Y_{i t}=f\left(X_{i t} ; X_{i j t} ; R_{k t} ; Z_{i} ; \alpha_{i} ; \gamma_{t}\right)
$$

Where:

$$
Y_{i j t}=0,1,2, \ldots
$$

$Y_{i j t}$ denotes the count of new firms of type $j$ in area $i$ at time $t . X_{i t}$ is a matrix of explanatory variables that vary by area $i$ and time $t . X_{i j t}$ is a matrix of explanatory variables that vary by by area $i$, time $t$ and firm-type $j . R_{k t}$ is a matrix of explanatory variables that vary at a more aggregated regional level $k$ and time t. $Z_{i}$ is a matrix of time-invariant explanatory variables, $\alpha_{i}$ are area fixed effects, which are included in some specifications. $\gamma_{t}$ are time-dummies.

\subsubsection{Econometric considerations}

The econometrics literature encourages the use of fixed-effects models in panel-data estimations. This allows for a limited form of time-invariant endogeneity, $\alpha_{i}$, which can be eliminated by differencing transformations, enabling consistent estimation of the coefficient of interest, $\beta$, for the time-varying regressors.

In this case, a number of the explanatory variables, particularly those relating to the accessibility of the locations are time-invariant. Further, high-proportions of areas never receive any firms. This makes the differencing transformation problematic as these areas and variables drop out of the estimations. To account for this,

\footnotetext{
${ }^{5}$ Choice models are based on McFadden's random utility maximisation framework (McFadden et al., 1973). For recent examples see Pusterla and Resmini (2007); Siedschlag et al. (2013); Barrios (2006). For count models see Jofre-Monseny et al. (2011); Bhat et al. (2014). Research comparing the relative merits of each approach includes Guimaraes et al. (2003) and Schmidheiny and Brulhart (2011).
} 
area fixed effects are included as dummy variables, along with year fixed effects in a range of random effects and population-averaged specifications. We also report results from a first-differenced fixed effects model as a robustness check in the supplementary material. This is not our primary specification as using this model significantly reduces our sample size due to reasons discussed. Results from a range of random effects models are also reported as a robustness check $^{6}$.

Related to the issue of over-dispersion is the excess zero problem. This arises when there are a large number of areas with zero counts for firms, or zero counts for firms of a specific type. Zero-inflated and hurdle-count models are widely used to accommodate this problem. Both of these models are finite mixture models with two components, the zero-truncated probability mass function and the untruncated probability mass-function (Cameron and Trivedi, 2013).

Our choice of unit helps to ameliorate this issue (discussed in more detail in Section 2.4 and the supplementary material). We include only those locations which are at or above the 75 th percentile of employment density in Ireland. A plausible argument can be made that all of these areas are legitimate potential locations for new businesses, negating the need to explicitly model the zeros as a separate process. As a robustness check we also report results from zero-inflated Poisson and zero-inflated Negative-binomial estimators and the results hold.

Another potential issue is spatial dependence. When modelling firm counts at a disaggregate spatial level, spatial dependence could exist in the dependent variable, independent variables, or through unobserved factors that affect the residuals. This has been widely observed in the literature on business location choices (Guimaraes et al., 2004; Alama-Sabater et al., 2010). Practical difficulties exist in modelling spatial dependence in a nonlinear panel setting. Much of the currently available toolboxes ${ }^{7}$ deal with spatial dependence in an OLS panel setting, although recent work by Bhat et al. (2014) has developed a spatial multivariate count model in a panel setting, implemented in Gauss.

We mitigate this problem by choosing a specific unit of observation that significantly reduces the potential for spatial spill-overs (described in detail in Section 2.4 and the supplementary material). A series of robustness checks are also performed using a range of spatial econometric models. As recommended by Halleck Vega and Elhorst (2015) we start with the spatial lag of X (SLX) model. Following this we also estimate a spatial autoregressive model (SAR) and a spatial Durbin model (SDM) model. Discussion of the lagged variables and weights matrix $\mathrm{W}$ is in Section 4.2

Formally the SLX model we estimate can be described by:

$$
Y_{i t}=\alpha_{i}+X_{i t} \beta+W \cdot X_{i t} \lambda+\gamma_{t}+\epsilon_{i t}
$$

\footnotetext{
${ }^{6}$ The supplementary appendices provide results from a range of alternate model specifications.

${ }^{7}$ Such as those in Matlab provided by Elhorst (2012) and LeSage.
} 
The SAR model by:

$$
Y_{i t}=\alpha_{i}+\rho W \cdot Y_{i t}+X_{i t} \beta+\gamma_{t}+\epsilon_{i t}
$$

The SDM by:

$$
Y_{i t}=\alpha_{i}+\rho W \cdot Y_{i t}+X_{i t} \beta+W \cdot X_{i t} \lambda+\gamma_{t}+\epsilon_{i t}
$$

\subsection{Identification}

The potential endogenous relationship between the placement of broadband infrastructure and economic activity has been highlighted by a number of other authors (Van Gaasbeck, 2008; Mack et al., 2011; Kolko, 2012; Mack and Rey, 2014). This may arise from reverse causality between broadband availability and economic activity, such as new business counts, employment, payroll and house rents, or omitted variable bias due to unobserved heterogeneity in the locations.

The economics of DSL broadband roll-out, like most other networks is largely driven by population density. Reverse-causality is more likely to link DSL to employment levels in existing firms, not new firm formation. By restricting the analysis to new firms in each year, and by controlling for the pre-existing employment levels in each area at every time period, this problem is mitigated.

The locations of the MANs was decided based on applications made by the relevant local authorities. An area fixed-effect is used to control for unobserved area characteristics in these locations that might be related to new firm counts, and a time-varying dummy variable identifies the effect beginning with the period the network was enabled.

Local labour markets are represented by the proportion of people with a third level qualification, the unemployment rate and relative employment compensation. An influx of new firms may affect all of these measures. To account for this, we run a robustness check keeping these variables unchanged at their 2002 levels and the results hold.

To further ensure robustness, all explanatory variables are lagged by one period in all estimations, and further robustness checks are undertaken using variables lagged by two periods.

\subsection{Data overview}

An overview of the assembled data-set and it's sources is provided in Table 1. Descriptive statistics on all variables used can be found in the appendices. 
Table 1: Variables and their sources

\begin{tabular}{lllll}
\hline Variable Type & Variable & Spatial Level & Frequency & Source \\
\hline Firm & Firm location, sector, size, entry year & Urban Field & annual & Department of Jobs Enterprise and Innovation (DJEI) \\
Broadband & Local access: Eircom DSL enabled exchange & geocoordinates & annual & Eircom/Eir \\
& Middle mile: MAN data & geocoordinates & annual & B \\
& Backhaul competition: BT backhaul & geocoordinates & annual & BT \\
Agglomeration & Localisation (sector share of tot employment) & Urban Field & annual & DJEI \\
& Specialisation(spatial HH index). & Urban Field & annual & DJEI \\
& Firms of own nationality & Urban Field & annual & DJEI \\
Accessibility (distance to:) & Motorway network & Urban Field & annual & Author's calculations using Microsoft MapPoint \\
& Rail Stations & Urban Field & 2007 & as above \\
& Airports & Urban Field & 2007 & as above \\
Human Capital & Distance to University/IT & Urban Field & 2007 & as above \\
& Proportion with third level qualification & Urban Field & $2001,2006,2011$ CSO Population Census \\
Demographic & Population in persons & Urban Field & $2001,2006,2011$ & CSO Population Census \\
& Population density & Urban Field & $2001,2006,2011$ & CSO Population Census \\
Labour market & Relative labour cost & County & annual & CSO Regional Accounts \\
& Unemployment rate & Urban Field & $2001,2006,2011$ CSO Population Census \\
\end{tabular}


Table 2: Firms: Most frequent NACE 4 digit categories by sector

\begin{tabular}{|c|c|c|c|}
\hline Sector Type & Sector & Domestic firms & Foreign firms \\
\hline \multirow[t]{15}{*}{ High-tech } & Computer consultancy activities & 419 & 23 \\
\hline & Other information technology and computer service activities & 105 & 39 \\
\hline & Other software publishing & 59 & 0 \\
\hline & Computer programming activities & 56 & 28 \\
\hline & Business and other management consultancy activities & 55 & 0 \\
\hline & Artistic creation & 44 & 0 \\
\hline & Engineering activities and related technical consultancy & 44 & 0 \\
\hline & Data processing, hosting and related activities & 42 & 4 \\
\hline & Manufacture of irradiation, electromedical and electrotherapeutic equipment & 35 & 0 \\
\hline & Other education n.e.c. & 32 & 0 \\
\hline & Computer facilities management activities & 0 & 31 \\
\hline & Manufacture of pharmaceutical preparations & 0 & 14 \\
\hline & Manufacture of electronic components & 0 & 5 \\
\hline & Other Manufacture & 0 & 5 \\
\hline & Manufacture of computers and peripheral equipment & 0 & 4 \\
\hline \multicolumn{2}{|l|}{ Total high-tech } & 1563 & 171 \\
\hline \multirow[t]{12}{*}{ Low-tech } & Other personal service activities n.e.c. & 87 & 0 \\
\hline & Manufacture of other food products n.e.c. & 51 & 0 \\
\hline & Processing and preserving of meat & 40 & 0 \\
\hline & Manufacture of other fabricated metal products n.e.c. & 32 & 0 \\
\hline & Manufacture of metal structures and parts of structures & 27 & 0 \\
\hline & Manufacture of medical and dental instruments and supplies & 24 & 19 \\
\hline & Other specialised construction activities n.e.c. & 24 & 0 \\
\hline & Manufacture of other furniture & 21 & 0 \\
\hline & Recovery of sorted materials & 21 & 0 \\
\hline & Manufacture of other plastic products & 20 & 4 \\
\hline & Manufacture of metal structures, tools and metal treatment & 0 & 6 \\
\hline & Other Manufacture & 0 & 5 \\
\hline Total Low-tech & & 1141 & 42 \\
\hline \multirow[t]{8}{*}{ Financial } & Other financial service activities, except insurance and pension funding n.e.c. & 7 & 0 \\
\hline & Insurance, pension funding and leasing companies & 7 & 0 \\
\hline & Trusts, funds and similar financial entities & 5 & 0 \\
\hline & Other credit granting & 5 & 0 \\
\hline & Non-life insurance & 4 & 0 \\
\hline & Other activities auxiliary to financial services, except insurance and pension funding & 3 & 0 \\
\hline & Fund management activities & 0 & 8 \\
\hline & Insurance and other financial services & 0 & 7 \\
\hline Total Financial & & 33 & 19 \\
\hline
\end{tabular}

Notes: Fields containing less than 3 firms merged to preserve anonymity 


\subsection{Unit of analysis: "Urban Fields"}

While it is tempting to exploit the rich cross-sectional variation of Irish Electoral Divisions (EDs) as a unit of analysis for firm locations, choosing this unit creates a severe excess zero problem. Many areas are never chosen by firms and these are qualitatively different from potential firm locations. On the other hand, choosing larger units such as counties reduces this problem but creates an area that may be internally heterogenous, with this variation masked by aggregation.

In terms of the choice firms make, it is more likely to be at town-level. Therefore new units of analysis which we refer to as "Urban Fields" are created, as per Table 3. These areas are either single Electoral Divisions (EDs) or are aggregations of contiguous EDs which are approximately at or above the 75th percentile of employment density, based on the 2011 Census Place of Work School or College (POWSCAR) and merged using GIS software ${ }^{8}$. Any EDs which do not fall into this category are not considered for the analysis. This selection covers 97 percent of all new foreign firms and 75 percent of all new domestic firms in the sample period.

While this aggregation (like any other) may also induce spatial dependence that is difficult to diagnose, these units were created as the best compromise between the rich cross-sectional variation afforded by a more disaggregate unit, mitigating the excess-zero problem, and creating areas that firms might realistically choose between. The analysis does not include the Dublin City region, as this area is a uniquely attractive location for new firms in Ireland.

Table 3: Irish Census geographical areas

\begin{tabular}{lc}
\hline Geographical Areas & No of geographic units \\
\hline Legal Towns and Cities & 85 \\
Urban Fields* & 192 \\
Towns/Cities (Settlements) & 824 \\
Electoral Divisions (EDs) & 3440 \\
\hline
\end{tabular}

Note: Urban Fields are based on the author's calculations. These are aggregations of contiguous EDs at or above the 75th percentile of employment density

In total we aggregate 858 EDs to create 192 Urban Fields. This also encompasses the entire set of "Legal Towns and Cities", and 316 areas of the set of 824 "Towns/Cities (Settlements)". These are a heterogenous group and contain both urban and rural areas, indeed 42 percent of the Towns/Cities (Settlements) within our sample are considered rural by the Central Statistics Office in Ireland. This is defined as any area with a population of less than 1500 inhabitants. Of those rural areas included in our analysis, more than 50 percent have a total population of less than 800 people.

Comparing firm counts in the EDs located within Urban Fields to those outside in Table 4, average firm

\footnotetext{
${ }^{8}$ Detail on the relevant EDs and corresponding Urban Fields are available on request. There are approximately 3400 EDs in Ireland.
} 
counts per ED and year differ by one order of magnitude between Urban Field and non Urban Field.

Table 4: Average firm counts per ED and year

\begin{tabular}{llrrr}
\hline & FDI & Domestic & High-tech & Low-tech \\
\hline Urban Fields & 0.050 & 0.344 & 0.276 & 0.097 \\
Non-Urban Fields & 0.001 & 0.038 & 0.017 & 0.021 \\
\hline
\end{tabular}

\subsection{Firm location variables}

Dependent variables come from the Department of Jobs, Enterprise and Innovation (DJEI) Annual Employment Survey. This is an annual census of employment in all manufacturing and internationally-traded services companies in Ireland. This survey has been administered since 1972 by the agency formally known as Forfás, now subsumed within DJEI. This dataset contains firm-level annual data on employment, NACE 4 digit sector, location (geocoordinates), entry/exit, and whether a firm is majority foreign or domestic owned. Details of all new entrants by sector is displayed in Table 2. This survey under-represents the services sector (Lawless, 2012), but contains almost the full population of foreign firms and manufacturing firms (Barrios, 2006).

This dataset allows us to track the entry of all new firms over our sample period. Entry is recorded as the first time a firm records positive employment numbers in the dataset. The majority of new foreign entrants in our sample are high-tech knowledge intensive services providers. Domestic firms again are predominantly involved in services but there is a greater balance of firms across other sectors within the economy. For a detailed breakdown see the supplementary appendices.

\subsection{Infrastructure}

This subsection discusses the explanatory variables, which we divide into categories. Further detail is provided in the supplementary material.

\subsubsection{Broadband}

To deliver broadband services to businesses and homes, network operators need to put suitable infrastructure in place. Because we do not directly observe the set of network elements used by each firm to obtain broadband access, we have constructed three proxies for the availability of infrastructure that aim to capture the main local sources of variation in the quality and cost of broadband available across Ireland.

The consumer's premises is connected to an "access network", sometimes referred to as the "last mile". This connection may be provided using various different technologies, e.g. fibre optic cable, copper wire, or fixed wireless connection. DSL technology uses traditional telephone lines to deliver broadband services and 
during our sample period it was by far the main technology used to deliver local broadband access ${ }^{9}$. $75 \%$ of Irish enterprises with 10 or more employees reported having access to DSL services in 2012, 30\% had access to other forms of fixed wired connections (some had both) (CSO, 2013). Larger firms in particular were more likely to have other types of fixed connections, probably reflecting a need for higher download speeds than those supported by DSL. Many firms also had some form of mobile broadband access, e.g. via smartphones. Cable broadband plays only a minor role in serving Irish businesses. According to a 2013 survey commissioned by the national regulatory authority, ComReg, $7 \%$ of SMEs in urban areas and 3\% in rural areas reported that their main fixed broadband provider was UPC, the only provider in the market offering cable broadband (RedC, 2013).

Data traffic from local access connections is concentrated at nodes which in some areas are situated on a "middle mile" network such as a local fibre optic ring around a town. Larger firms, or those wishing to have higher access speeds, may connect directly to these middle mile networks and obtain higher speed service at lower cost than was formerly available using leased line services. Finally, longer distance "backhaul" connections are required to bring regional traffic flows together, linking all areas to the internet. Backhaul services are available across Ireland, but some places have more competition in the supply of backhaul than others. Competitive supply should reduce the cost of internet access to firms, ceteris paribus.

Ultimately it is an empirical question which, if any, of these levels of network infrastructure affect different sorts of firms choices about where to locate. Below we describe how each proxy is constructed

2.6.1.1 Local access. Developing a meaningful and accurate representation of broadband availability at a local level can be difficult. Much of the prior research into how broadband affects economic activity has been based in the US, and as outlined by Flamm in Chapter 10 of Taylor and Schejter (2013), many errors and inconsistencies arise when using Federal Communications Commission (FCC) zip-code level data to measure broadband. The proxies available to us have some advantages over the US metrics.

In this paper, the proxy for the availability of local broadband access services in an area is based on data provided by Ireland's former incumbent telecoms operator, Eircom. This panel dataset captures the availability over time of DSL services in 1,060 local telecoms exchange areas. We have data on the proportion of enabled exchanges in each area for each time period and we use this to create dummy variables which identify the period from which DSL was enabled in an area ${ }^{10}$.

Between 2001 and 2010, Eircom rolled out basic broadband services to local exchanges across the country. Enabling went from 0-100\% for most parts of the country over our sample period with significant geographic

\footnotetext{
${ }^{9}$ The dataset is an updated version of the one employed by Haller and Lyons (2015) to look at broadband adoption and firm productivity in Ireland.

${ }^{10}$ Proportions were used in initial estimations but dummy variables proved to have greater explanatory power in this case.
} 
variation $^{11}$. This proxy is probably more appropriate for SMEs than for larger enterprises; the largest firms would likely have used leased line infrastructure which could have been provided anywhere - at a price. However, rollout of DSL access is still a reasonable proxy for the availability of cost-effective broadband service for most of the firms in our sample.

2.6.1.2 Middle mile infrastructure. In 2004 the Irish Government funded an initiative to roll-out wholesale, open-access fibre optic infrastructure, known as the Metropolitan Area Networks (MANs) scheme. The MANs are town-level fibre rings, which provide a high bandwidth network to authorised operators, in turn allowing them to sell high capacity broadband services to end-users. The network was rolled out in two phases: phase 1 covered 28 locations and began in 2004, phase 2 covered an additional 66 locations and began in 2009 (some of these are illustrated in Fig. 1). The scheme focused on areas outside the Dublin city region, which has greater access to broadband infrastructure due to its high population density and concentration of business activity. As the MANs are a middle-mile infrastructure, users require local access to the nearest MAN and also local backhaul infrastructure to connect to the global network. Our proxy variable "MAN effect dummy" is set equal to 1 if a MAN was in operation in the Urban Field during a given year, and 0 otherwise. We also include a "MAN area fixed-effect" variable to capture any omitted characteristics of these areas that might also be correlated with new firm formation

\footnotetext{
${ }^{11}$ This is illustrated graphically in the supplementary material
} 


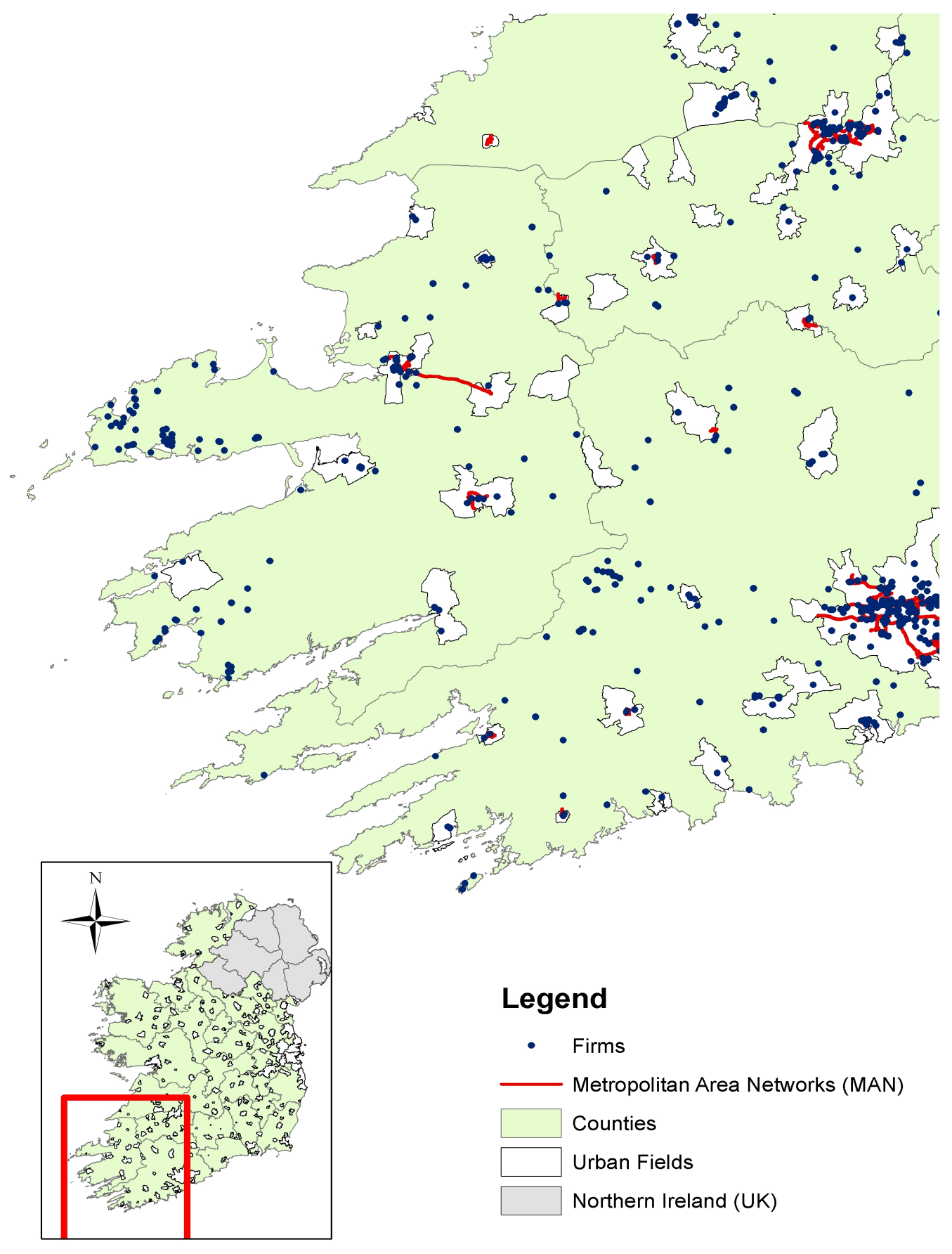

Figure 1: Map of Urban Fields and Metropolitan Area Networks for South-East of Ireland

2.6.1.3 Backhaul proxy. There is no comprehensive public source of mapping data on the development of Ireland's backhaul networks over time. Eircom offers backhaul services across much of the country, but as a proxy for the availability of backhaul competition in an area we use data provided by BT Ireland. BT leases a national duct network from CIE (Irish National Rail Network) in which fibre is laid along the railway lines 
with transmission access points at towns located along the routes. In addition to this, CIE have metropolitan access fibre networks laid along the roads of the major cities and some of the smaller towns. We have the geocoordinates of each node in this network, and the installation date of each wholesale On-Net circuit, allowing us to map it spatially and temporally. Here too, we use a dummy variable - "MAN increased backhaul" for the availability of BT's backhaul network in a given Urban Field.

\subsubsection{Motorways and other infrastructure}

The drive times to motorway junctions, airports, railway stations, universities and institutes of technology (IT) were calculated using Microsoft MapPoint in conjunction with the MP MileCharter utility, which can compute travel times and distance between multiple points. Specifically, the shortest travel times are calculated between the centroid of each electoral district (ED) in Ireland and the respective infrastructure. These are then averaged to calculate the drive time from the centroid of each Urban Field. The travel times relate to drive time by car and the route optimisation takes into account the quality of the underlying road infrastructure by allowing the average speeds for different types of roads to differ. For example the average speed in urban streets is assumed to be $32 \mathrm{~km} / \mathrm{h}$ while that on motorways is assumed to be $104 \mathrm{~km} / \mathrm{h}$. The inverse drive-times are then calculated to characterise proximity.

Transport infrastructure, and in particular the motorway network underwent significant extensions in Ireland over our sample period, with $86.1 \%$ of the current Irish network constructed during this timeframe. In order to capture these changes we include panel data on the driving time from the centroid of each Urban Field to the nearest motorway junction. Fig. 2 highlights the expansion over our sample period, and contrasts this with some international examples. 


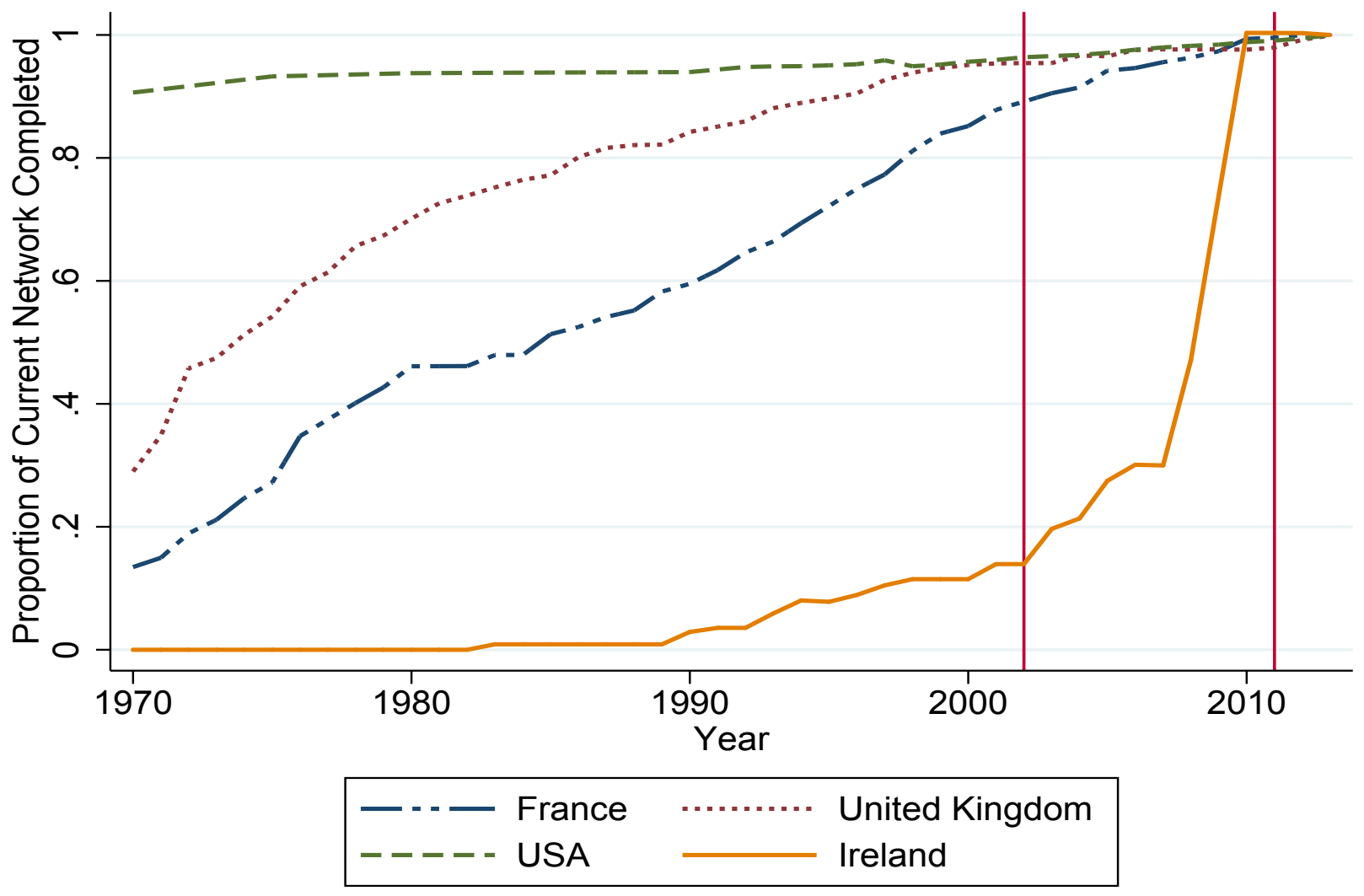

Figure 2: International comparison of motorway extension, 1970-2013. Sources: The data for the USA is from the Bureau of Transportation, for the UK from the Office of National Statistics, for France from EUROSTAT and for Ireland from the National Roads Authority (now Transport Infrastructure Ireland). Note: Vertical lines indicate sample period.

Equally important for our analysis is where the expansion occurred. Fig. 3 geographically illustrates the change in driving times between 2002 and 2011 in Ireland. During this period the network was extended to link most major urban centres, with the exception of the south-west and north-west, to the capital city, Dublin.

Other accessibility measures include the driving time in minutes from the centroid of each Urban Field to the nearest airport, train station, port, university and IT. This data is only available for 2007. However relatively little change occurred in these measures over time.

\subsection{Agglomeration and human capital}

Using the DJEI Annual Employment Survey we calculate a number of alternate agglomeration measures. These include economies of specialisation and diversification, along with a range of measures that reflect employment size and density by sector, skill-level and location of owner.

The sector share of total employment in each Urban Field in each year is defined as: 


\section{2}

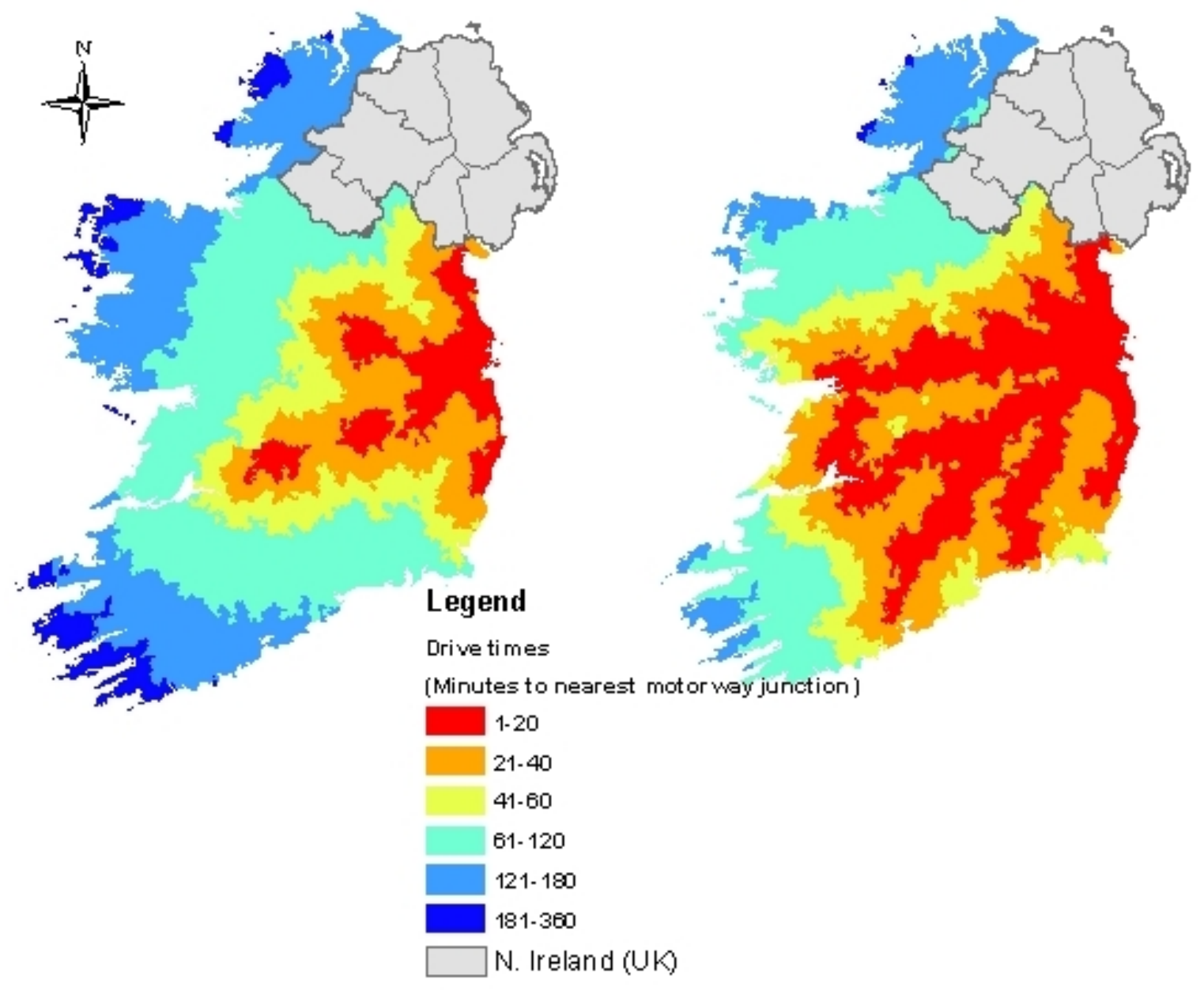

Figure 3: Location of motorway extensions, Ireland 2002-2011

$$
s_{i j}(t)=\frac{E_{i j}(t)}{\sum_{i=1}^{I} E_{i j}(t)}
$$

Where $E_{i j}(t)$ is employment in sector $i$ in Urban Field $j$ at time $t$, where $i=1,2, \ldots, I, j=1,2, \ldots, J$ and $t=1,2, \ldots, T$. and $\sum_{i=1}^{I} E_{i j}(t)$ is total employment across all sectors in Urban Field $j$ at time $t$.

The measure of specialisation is calculated as the sum of square of each sectoral employment share in each Urban Field (the spatial Herfindahl-Hirschman index) $)^{12}$.

$$
u_{i j}(t)=\sum_{i=1}^{I}\left(s_{i j}(t)\right)^{2}
$$

We follow McHenry (2014) by measuring human capital as the the proportion of the population in each area

\footnotetext{
${ }^{12}$ Sectors are based on a Eurostat aggregation of NACE 2 digit codes. For details see http://epp.eurostat.ec.europa.eu.
} 
with a third-level degree. This data and information on the unemployment rate come from the CSO Population Census. Data from the 2002, 2006 and 2011 Censuses are used in creating these variables.

To proxy for the relative wage costs employers face, Compensation of Employees data from the CSO County Incomes and Regional Accounts is included. These are available on an annual basis at county level.

\subsection{Demand-side variables}

Many of the previously mentioned measures represent supply-side factors. Although, relative labour costs, unemployment, human capital and total employment in each Urban Field will also capture local demand. To further characterise access to local markets a variable called "centrality" is calculated which captures the proximity of each Urban Field to population centres in Ireland.

$$
c_{i}(t)=\sum_{j=1}^{J} \frac{P_{j}(t)}{D_{i j}}
$$

$c_{i}(t)$ is the centrality of Urban Field $i$ at time $t$, where $i=1,2, \ldots, I$, and $t=1,2, \ldots, T$. $P_{j}(t)$ is the population of each Electoral Division (ED) $i$ at time $t, j=1,2, \ldots, J . D_{i j}$ is the drive time in minutes from each Urban Field $i$ to each ED $j$.

\section{$3 \quad$ Econometric results}

In this section we report our empirical results. Time trends are captured using year dummies in all models. The coefficients on these terms are significant and negative from 2006 onwards, consistent with the economic downturn experienced in Ireland during this time ${ }^{13}$. In total we examine 190 Urban Fields in a balanced panel of 10 time periods.

For all estimations, average marginal effects (AME) are reported. The AME is the average of the marginal effects taken at each $x=x_{i}{ }^{14}$. In all cases, the unit change in $y$ for an associated change in $x$ is presented: as broadband variables are binary, the effect on $y$ of a discrete change in the base level of $x$ from $0-1$ is examined; as all other variables are continuous, the effect on $y$ of a percentage change in $x$ is examined. Given this, the magnitude of the effect size for all variables are comparable to each other and reveal which factors have most influence on new business establishments. Results are reported for all variables, but particular emphasis is placed

\footnotetext{
${ }^{13}$ Additional analysis examining the effect of ICT over time and over the boom/bust period is also performed. These results are confined to the supplementary material, as low rates of new entrants for certain splits make it more difficult to establish robust estimates.

${ }^{14}$ The value of marginal effect will depend on the point at which they are evaluated. For non-linear models the AME is generally larger than the marginal effect at the average (MEM) and in practice can be similar to the coefficients estimated with OLS models. For policy analysis the AME or marginal effect at representative values (MER) are recommended over the MEM. See Cameron and Trivedi (2013) for further details.
} 
on the broadband results, given the focus of this research and greater confidence regarding the robustness of these effects.

For comparability purposes we also report elasticities $(e y / e x)$ and semi-elasticities $(e y / d x)$ for all reported marginal effects presented in Table 5. This allows for an estimation of the percentage increase in new firms for an associated change in the independent variable. Regarding the economic interpretation of our results, we will focus primarily on the marginal effects for all subsequent results. We take this approach because our sample includes relatively few new entrants. Focusing on elasticities might give the impression that infrastructure improvements drew in a larger number of new entrants (in absolute terms) that there actually were. Also, given that the base rate of new foreign entrants is significantly lower than that of new domestic entrants a higher elasticity for foreign firms does not yield more new foreign entrants than domestic ones. ${ }^{15}$.

Ireland experienced an extreme economic expansion and contraction during our period of analysis. We control for annual trends using year fixed effects, however the effect of deployment may differ depending on which period is examined

\subsection{New business establishments by location of owner}

The first section focuses on a split between foreign and domestic-owned firms. Considering the broadband variables first, it appears that the availability of first-generation, last-mile DSL infrastructure in an area was a statistically significant determinant of new domestic firms, but not foreign (columns (1) and (2) respectively of Table 5), resulting in 0.588 (or 57\%) more firms in an area. The MAN effect dummy is positive and significant for foreign firms but not domestic. On average having a MAN operational in an area is associated with 0.103 (or $83 \%$ ) more new foreign firms.

Accessibility is represented in the model by the inverse drive-time to the nearest motorway junction, airport and train station. For foreign firms, all of these measures have a positive sign, indicating that firms value proximity. The relative magnitudes suggest an implicit ranking. Access to airports is valued above access to motorway junctions which in turn is valued above access to train stations. Accessibility results were not statistically significant for domestic firms.

In terms of magnitude, halving the driving time from an area to the nearest motorway junction is associated with $0.037(18 \%)$ new foreign firms. Taken at the sample average of approximately 50 mins this would mean a 25

\footnotetext{
${ }^{15}$ Consider the DSL marginal effect reported in column (1) of Table 5. Having a local telephone exchange enabled for DSL broadband in an area results in 0.043 more foreign firms and 0.588 more domestic firms (although the coefficient on foreign is not statistically significant). Interpreting the corresponding elasticity in column (3), having an exchange enabled in an area results in $43.7 \%$ more foreign firm births and $57.5 \%$ more domestic firm births. Also see the elasticities and marginal effects on the specialisation variable. The elasticity for specialisation is larger for foreign firms (-232\%) than for domestic (-96.6\%), but the reverse is true for the marginal effect, the magnitude is smaller for foreign (-0.132) than for domestic (-0.244). This is explained by differences in the observed count of new business establishments. For foreign firms a larger probability elasticity can result in a smaller marginal effect, because we observe significantly more new domestic firms than foreign firms. The coeff $=$ ME. $\frac{1}{y}$, where $\bar{y}_{\text {foreign }}=0.11$ and $\bar{y}_{\text {domestic }}=0.9$
} 
minute reduction in drive time. By comparison, having a middle-mile fibre broadband network made operational in an area is associated with $0.103(83 \%)$ new foreign firms.

Considering the agglomeration variables next, it appears firms value diversity of skills in a location above specialisation. This result applies to both foreign and domestic firms and holds throughout various sample splits employed in subsequent sections. This is consistent with previous research examining firm location choices in Ireland (Barrios, 2006). Areas with pre-existing high proportions of foreign(domestic) employment are associated with increased foreign(domestic) firm birth rates. Employment density is positive and significant for domestic firms but not foreign. The pre-existing total employment in each area is included as a scale variable and is an important determinant of new foreign and domestic firms.

Both inverse drive-time to the nearest third-level institute and the proportion of the population with thirdlevel qualifications are significant factors in new foreign and domestic firm formation. This holds throughout our analysis and is one of the key messages of this research. Also, the magnitude of the effect on third level distance is considerably larger than any of the other accessibility measures reported. A doubling (or 100\% increase) in educational attainment is associated with 0.479 (286\%) more foreign and 0.621 (241\%) more domestic firms. Human capital is key for both entrepreneurship and the spatial distribution of FDI. Section 3.4 will further explore the interaction of this effect with ICT provision.

Relative labour costs do not have significant effects on either foreign or domestic firms. Interestingly, for new foreign establishments there is a positive and significant coefficient on the variable representing the proportion of the labour force who are unemployed. Further estimation reveals that this effect only exists when human capital is controlled for, indicating that firms may be locating where there is an excess supply of skilled labour. Higher unemployment rates may also put downward pressure on wages. This result is consistent with Coughlin et al. (1991). However, significance is weak and any inference must be tempered with caution.

Finally, centrality or access to domestic markets in not significant in any of our estimations.

\subsection{New business establishments by skill-level}

Foreign and domestic firms are now pooled and then split by the skill-level of their employees (columns (1) and (2) respectively of Table 6). This is to examine if patterns emerge at this level that are common to both.

The initial roll-out of DSL has impacted both high-tech and low-tech firms, although the magnitude of this effect is much greater for high-tech firms. Another MAN category is now created, which allows examination of the impact of increased competition in the backhaul market using data provided by BT. The positive impact of the MANs appears confined to the high-tech sector. There is a slight premium in areas where MANs have access to greater competition in the local backhaul market above those without. 
Motorway access is important for low-tech firms. The agglomeration results again underline the importance of skills diversity as opposed to specialisation in attracting new firms of all types. Both human capital measures emerge again as significant determinants of both new high-tech and low-tech business establishments. The effect is much larger for high-tech firms.

\subsection{New business establishments by skill-level and location of owner}

Further sample splits are undertaken to compare firms by skill-level and location of their owner (columns (2-6) of Table 6).

Initial DSL roll-out is again important for all firm types with the exception of low-tech foreign firms, but much more so for those in the high-tech sector. The impact of middle-mile fibre is again concentrated in the high-tech sectors, and there is a premium where increased competition in backhaul exists.

Motorway access emerges as significant for high-tech foreign and low-tech domestic firms. High-tech foreign firms also value proximity to airports, the effect size is more than double that of motorways. Low-tech foreign firms appear to value proximity to train stations. This variable may also be picking up the fact that most large towns have train stations and foreign firms almost exclusively locate in large urban areas. Human capital once again emerges as an extremely powerful determinant of location for all firms. This effect is particularly strong for high-tech firms.

High-tech foreign firms appear to be drawn to areas with higher relative wages. The unemployment rate is again significant. The simple correlation of unemployment and new firm births is negligible, ${ }^{16}$ and only present once labour cost and quality are controlled for, indicating if anything an excess labour supply effect.

\subsection{Interaction of ICT and human capital}

Previous research has suggested that certain areas are better equipped to absorb the effects of new technology productively (Mack and Faggian, 2013). Given this, we are interested in how the impact of ICT varies across areas with differing levels of educational attainment. To explore this question we examine the interaction between traditional DSL, fibre broadband and human capital for new firm formation. We do not distinguish between MANs with and without backhaul in this specification, otherwise the model is identical to that used in previous estimations.

Fig. 4 illustrates this effect, by comparing the difference in expected firm counts in areas with and without ICT at different levels of educational attainment. This is examined for DSL and MANs separately, and for foreign, domestic and high-tech firms.

\footnotetext{
${ }^{16}$ If anything this effect is negative. Correlation with high-tech FDI is -0.02 and high-tech domestic -0.06 .
} 
Table 5: Count of new establishments at Urban Field level 2002-2011, by location of ownership and skill-level

(1)

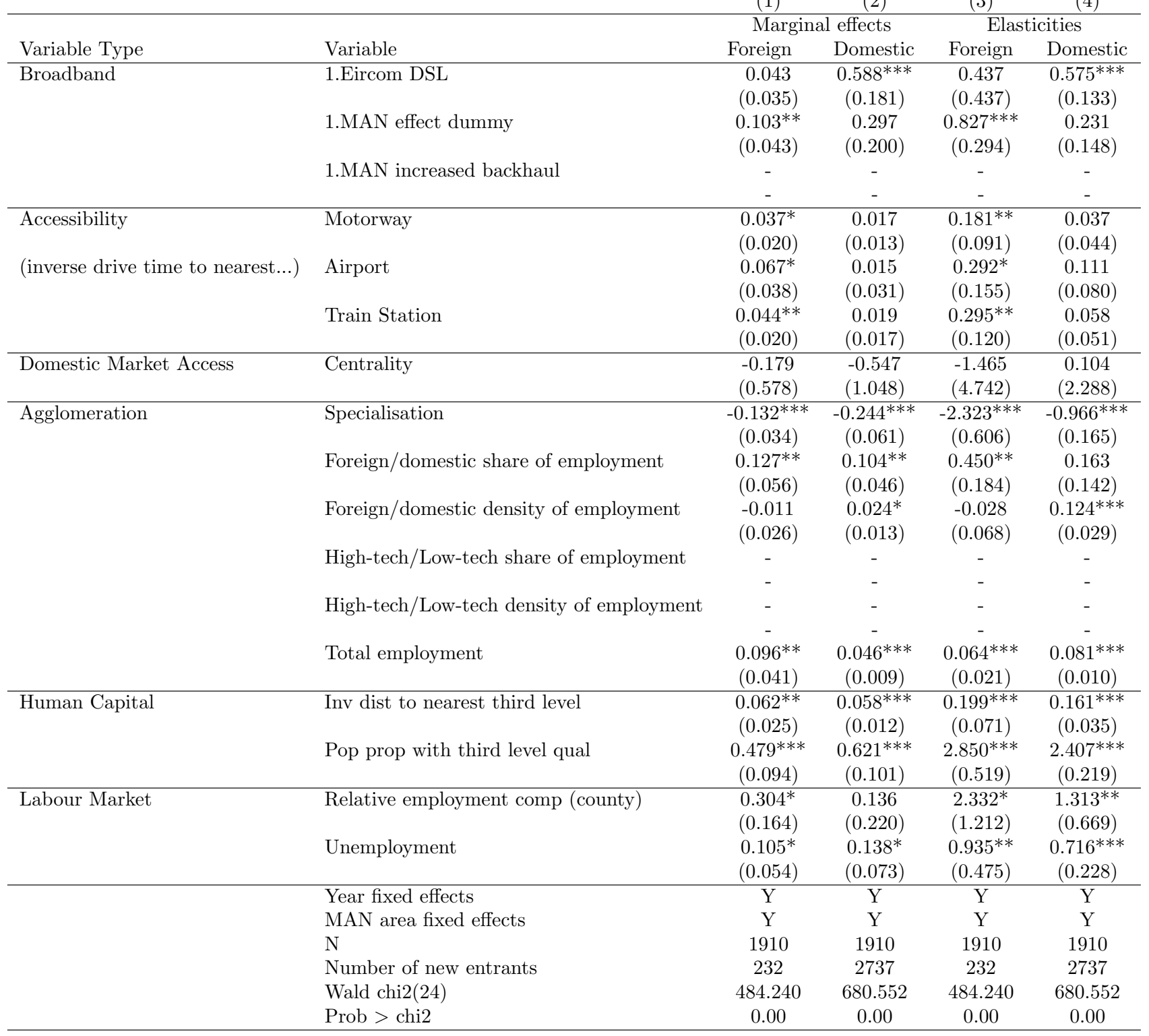

Notes: This table reports results from NB population-averaged panel estimation with cluster robust standard errors. The dependent variable in all regressions is the count of new firms in each year in each period. All broadband variables are binary and marginal effects and elasticities are reported: dy/dx and ey/dx for factor levels is the discrete change from the base level. All other variables are continuous and results reported are semi-elasticities and elasticities: dy/ex and ey/ex. All explanatory variables are lagged by one period. The Dublin City area is omitted from all estimations. *** $\mathrm{p}<0.01, * * \mathrm{p}<0.05, * \mathrm{p}<0.1$. 
Table 6: Count of new establishments at Urban Field level 2002-2011, by location of ownership and skill-level

\begin{tabular}{|c|c|c|c|c|c|c|c|}
\hline \multirow[b]{3}{*}{ Variable Type } & \multirow[b]{3}{*}{ Variable } & (1) & (2) & $(3)$ & (4) & (5) & $(6)$ \\
\hline & & \multicolumn{2}{|c|}{ All Firms } & \multicolumn{2}{|c|}{ High-tech Firms } & \multicolumn{2}{|c|}{ Low-tech Firms } \\
\hline & & High-tech & Low-tech & Foreign & Domestic & Foreign & Domestic \\
\hline \multirow{6}{*}{ Broadband } & 1.Eircom DSL & $0.531^{* * *}$ & $0.142^{* * *}$ & $0.063^{* * *}$ & $0.455^{* * *}$ & 0.009 & $0.143^{* * *}$ \\
\hline & & $(0.103)$ & $(0.054)$ & $(0.020)$ & $(0.078)$ & $(0.007)$ & $(0.051)$ \\
\hline & 1.MAN effect dummy & $0.422^{* *}$ & -0.092 & $0.177^{* *}$ & $0.309^{*}$ & 0.003 & -0.095 \\
\hline & & $(0.192)$ & $(0.067)$ & $(0.088)$ & $(0.164)$ & $(0.013)$ & $(0.061)$ \\
\hline & 1.MAN increased backhaul & $0.683^{* * *}$ & 0.041 & $0.144^{* *}$ & $0.537^{* * *}$ & 0.017 & 0.014 \\
\hline & & $(0.237)$ & $(0.095)$ & $(0.072)$ & $(0.204)$ & $(0.017)$ & $(0.090)$ \\
\hline \multirow[t]{2}{*}{ Accessibility } & Motorway & 0.055 & $0.070^{* *}$ & $0.043^{* *}$ & 0.021 & 0.001 & $0.069^{* *}$ \\
\hline & & $(0.054)$ & $(0.029)$ & $(0.018)$ & $(0.046)$ & $(0.005)$ & $(0.028)$ \\
\hline \multirow[t]{4}{*}{ (inverse drive time to nearest...) } & Airport & 0.118 & 0.012 & $0.095^{* *}$ & 0.062 & -0.002 & 0.019 \\
\hline & & $(0.168)$ & $(0.065)$ & $(0.038)$ & $(0.132)$ & $(0.008)$ & $(0.061)$ \\
\hline & Train Station & 0.051 & 0.011 & 0.027 & 0.036 & $0.018^{* * *}$ & -0.001 \\
\hline & & $(0.060)$ & $(0.025)$ & $(0.019)$ & $(0.051)$ & $(0.006)$ & $(0.023)$ \\
\hline \multirow[t]{2}{*}{ Domestic Market Access } & Centrality & -1.811 & -0.161 & -0.505 & -1.317 & -0.135 & -0.115 \\
\hline & & $(2.977)$ & $(1.572)$ & $(0.649)$ & $(2.482)$ & $(0.122)$ & $(1.533)$ \\
\hline \multirow[t]{12}{*}{ Agglomeration } & Specialisation & $-0.448^{* * *}$ & $-0.203^{* * *}$ & $-0.076^{* *}$ & $-0.402^{* * *}$ & $-0.023^{* * *}$ & $-0.190^{* * *}$ \\
\hline & & $(0.096)$ & $(0.056)$ & $(0.030)$ & $(0.080)$ & $(0.008)$ & $(0.055)$ \\
\hline & Foreign/domestic share of employment & - & - & - & - & - & - \\
\hline & & - & - & - & - & - & - \\
\hline & Foreign/domestic density of employment & - & - & - & - & - & - \\
\hline & & - & - & - & - & - & - \\
\hline & High-tech/Low-tech share of employment & 0.116 & 0.088 & 0.001 & 0.123 & -0.012 & $0.097^{*}$ \\
\hline & & $(0.152)$ & $(0.056)$ & $(0.031)$ & $(0.126)$ & $(0.007)$ & $(0.055)$ \\
\hline & High-tech/Low-tech density of employment & 0.082 & 0.034 & 0.011 & 0.071 & 0.004 & 0.032 \\
\hline & & $(0.174)$ & $(0.028)$ & $(0.022)$ & $(0.144)$ & $(0.003)$ & $(0.028)$ \\
\hline & Total employment & $1.186^{* *}$ & $0.465^{*}$ & $0.084^{* *}$ & $0.867^{* *}$ & $0.007^{*}$ & $0.431^{*}$ \\
\hline & & $(0.604)$ & $(0.280)$ & $(0.040)$ & $(0.409)$ & $(0.004)$ & $(0.258)$ \\
\hline \multirow[t]{4}{*}{ Human Capital } & Inv dist to nearest third level & $0.314^{* * *}$ & $0.122^{* * *}$ & $0.055^{* * *}$ & $0.224^{* *}$ & 0.007 & $0.110^{* * *}$ \\
\hline & & $(0.116)$ & $(0.041)$ & $(0.018)$ & $(0.088)$ & $(0.007)$ & $(0.036)$ \\
\hline & Pop prop with third level qual & $3.096^{* * *}$ & $0.539^{* * *}$ & $0.496^{* * *}$ & $2.515^{* * *}$ & $0.077^{* * *}$ & $0.477^{* * *}$ \\
\hline & & $(0.643)$ & $(0.161)$ & $(0.100)$ & $(0.490)$ & $(0.019)$ & $(0.153)$ \\
\hline \multirow[t]{10}{*}{ Labour Market } & Relative employment comp (county) & 0.509 & -0.210 & $0.375^{* *}$ & 0.364 & -0.018 & -0.170 \\
\hline & & $(0.743)$ & $(0.313)$ & $(0.187)$ & $(0.613)$ & $(0.045)$ & $(0.297)$ \\
\hline & Unemployment & $0.530 * * *$ & 0.077 & $0.120 * * *$ & $0.461^{* * *}$ & 0.010 & 0.072 \\
\hline & & $(0.200)$ & $(0.091)$ & $(0.045)$ & $(0.162)$ & $(0.015)$ & $(0.086)$ \\
\hline & Year fixed effects & $\mathrm{Y}$ & $\mathrm{Y}$ & $\mathrm{Y}$ & $\mathrm{Y}$ & $\mathrm{Y}$ & $\mathrm{Y}$ \\
\hline & MAN area fixed effects & $\mathrm{Y}$ & $\mathrm{Y}$ & $\mathrm{Y}$ & $\mathrm{Y}$ & $\mathrm{Y}$ & $\mathrm{Y}$ \\
\hline & $\mathrm{N}$ & 1910 & 1910 & 1910 & 1910 & 1910 & 1910 \\
\hline & Number of new entrants & 1734 & 1183 & 171 & 1563 & 42 & 1141 \\
\hline & Wald chi2(24) & 849.634 & 871.072 & 448.354 & 610.618 & 386.781 & 411.366 \\
\hline & Prob $>$ chi 2 & 0.00 & 0.00 & 0.00 & 0.00 & 0.00 & 0.00 \\
\hline
\end{tabular}

Notes: This table reports results from NB population-averaged panel estimation with cluster robust standard errors. The dependent variable in all regressions is the count of new firms in each year in each period. All broadband variables are binary and marginal effects are reported: $\mathrm{dy} / \mathrm{dx}$ for factor levels is the discrete change from the base level. All other variables are continuous and results reported are semi-elasticities: dy/ex. All explanatory variables have been lagged by one period. The Dublin City area is omitted from all estimations. $* * * \mathrm{p}<0.01, * * \mathrm{p}<0.05, * \mathrm{p}<0.1$. 
The impact of ICT on all types of new firm counts in an area increases as human capital increases. For many firm types the effect is not significantly different from zero (based on $95 \% \mathrm{CI}$ ) when the proportion of the population with a third-level degree is below a certain threshold. This suggests that the effect of broadband on firm location is not independent of local educational attainment. The exception to this is the effect of DSL on domestic and high-tech firms.

There also appears to be a certain degree of non-linearity in the relationship. Expected firm counts in the presence of a MAN are higher in areas with greater average educational attainment, and the magnitude of the marginal effect increases as the level of educational attainment increases.
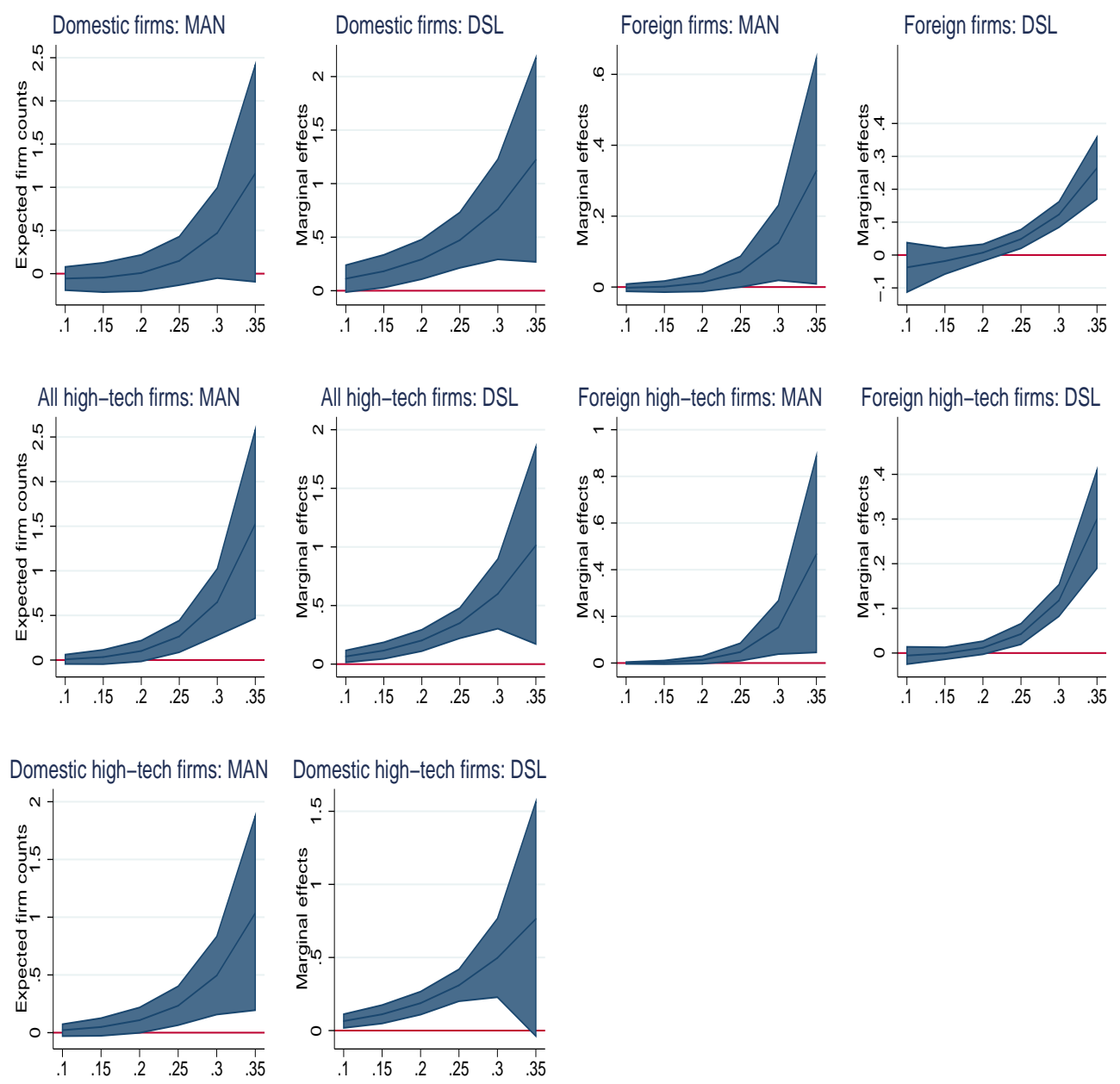

Figure 4: Expected firm counts in the presence of ICT at different levels of educational attainment

One particular feature of the relative levels of educational attainment by area is persistence over time, 
and there is very little change in the relative rankings of areas over our sample period ${ }^{17}$. Therefore, if ICT interacts with third level attainment in the manner discussed above, it might be the case that broadband rollout exacerbates differences between areas, in their ability to attract new business establishments. Urban Fields with higher educational attainment tend to be those more densely populated regions along the east coast - close to Dublin, and large regional cities and their surrounding Urban Fields. This is perhaps another channel through which the "urban bias" of broadband persists.

\section{Robustness}

As discussed in Section 2 several potential sources of error exist. To account for this we estimate multiple alternate specifications, comparing the results to our reported estimates for high-tech firms. The magnitude of the results change in some cases, but overall remain relatively consistent across all specifications. The results of all of these models are reported in the supplementary material.

\subsection{Excess zeroes}

By modelling at the Urban Field level we reduce the excess zero problem. To further account for these issues we also include other model specifications which explicitly model the zero observations as a separate process. The results of these zero-inflated negative binomial and poisson models are reported in the supplementary material. The magnitude of most coefficients reduce slightly in these specifications, but the significance remains throughout.

\subsection{Spatial dependence}

To account for potential labour market spill-overs we generate spatially lagged variables for the dependent variable; the unemployment rate; the proportion of the population with a third-level qualification; and the degree of labour market specialisation. We alos create a lagged-dependent variable. The spatial weights matrix is distance-based with the threshold at $50 \mathrm{~km}$. This allows estimation of a SLX, SAR and SDM models. The coefficients on the spatially lagged variables displayed in Table 7 are not significant, and their inclusion does not substantively alter our results.

\footnotetext{
${ }^{17}$ Spearman's rank correlation educational attainment over time for areas in our analysis is above 0.92 and significant at $1 \%$ for all time periods in our sample
} 
Table 7: Spatially lagged specifications

\begin{tabular}{|c|c|c|c|c|}
\hline \multirow[b]{2}{*}{ Variable } & \multirow{2}{*}{$\frac{\text { Reported results }}{\text { High-tech firms }}$} & \multicolumn{3}{|c|}{ Spatially lagged models } \\
\hline & & SLX & SAR & SDM \\
\hline \multirow[t]{2}{*}{ 1.Eircom DSL enabled exchange } & $0.531^{* * *}$ & $0.514^{* * *}$ & $0.533^{* * *}$ & $0.515^{* * *}$ \\
\hline & $(0.10)$ & $(0.10)$ & $(0.11)$ & $(0.10)$ \\
\hline \multirow[t]{2}{*}{ 1.MAN effect } & $0.422^{* *}$ & $0.394^{* *}$ & $0.434^{* *}$ & $0.400^{* *}$ \\
\hline & $(0.19)$ & $(0.19)$ & $(0.20)$ & $(0.20)$ \\
\hline \multirow[t]{2}{*}{ 1. MAN with increased backhaul } & $0.683^{* * *}$ & $0.666^{* * *}$ & $0.695^{* * *}$ & $0.675^{* * *}$ \\
\hline & $(0.24)$ & $(0.23)$ & $(0.24)$ & $(0.23)$ \\
\hline \multirow[t]{2}{*}{ Motorway } & 0.055 & 0.054 & 0.056 & 0.056 \\
\hline & $(0.05)$ & $(0.05)$ & $(0.05)$ & $(0.05)$ \\
\hline \multirow[t]{2}{*}{ Airport } & 0.118 & 0.13 & 0.11 & 0.11 \\
\hline & $(0.17)$ & $(0.16)$ & $(0.17)$ & $(0.17)$ \\
\hline \multirow[t]{2}{*}{ Train Station } & 0.051 & 0.049 & 0.054 & 0.054 \\
\hline & $(0.06)$ & $(0.06)$ & $(0.06)$ & $(0.06)$ \\
\hline \multirow[t]{2}{*}{ Urbanisation (diversity of employment) } & $-0.448^{* * *}$ & $-0.438^{* * *}$ & $-0.437^{* * *}$ & $-0.437^{* * *}$ \\
\hline & $(0.10)$ & $(0.09)$ & $(0.09)$ & $(0.09)$ \\
\hline \multirow[t]{2}{*}{ Sector share of employment } & 0.116 & 0.127 & 0.114 & 0.114 \\
\hline & $(0.15)$ & $(0.15)$ & $(0.15)$ & $(0.15)$ \\
\hline \multirow[t]{2}{*}{ Sector density of employment } & 0.082 & 0.077 & 0.08 & 0.08 \\
\hline & $(0.17)$ & $(0.17)$ & $(0.17)$ & $(0.17)$ \\
\hline \multirow[t]{2}{*}{ Total employment in island } & $1.186^{* *}$ & $1.170^{* *}$ & $1.227^{* *}$ & $1.227^{* *}$ \\
\hline & $(0.60)$ & $(0.55)$ & $(0.59)$ & $(0.59)$ \\
\hline \multirow[t]{2}{*}{ Inv distance to nearest TL institute } & $0.314^{* * *}$ & $0.320^{* * *}$ & $0.339 * * *$ & $0.339^{* * *}$ \\
\hline & $(0.12)$ & $(0.12)$ & $(0.12)$ & $(0.12)$ \\
\hline \multirow[t]{2}{*}{ Pop prop with third level qual } & $3.096^{* * *}$ & $3.201^{* * *}$ & $3.140^{* * *}$ & $3.140^{* * *}$ \\
\hline & $(0.64)$ & $(0.66)$ & $(0.68)$ & $(0.68)$ \\
\hline \multirow[t]{2}{*}{ Relative employment comp (county) } & 0.509 & 0.383 & 0.255 & 0.255 \\
\hline & $(0.74)$ & $(0.74)$ & $(0.75)$ & $(0.75)$ \\
\hline \multirow[t]{2}{*}{ Unemployment } & $0.530^{* * *}$ & $0.557^{* * *}$ & $0.543^{* * *}$ & $0.543^{* * *}$ \\
\hline & $(0.20)$ & $(0.20)$ & $(0.20)$ & $(0.20)$ \\
\hline \multirow[t]{2}{*}{ Spatial Lag - unemployment } & & -0.243 & & -0.229 \\
\hline & & $(0.17)$ & & $(0.17)$ \\
\hline \multirow[t]{2}{*}{ Spatial Lag - third level prop } & & -0.457 & & -0.496 \\
\hline & & $(0.30)$ & & $(0.31)$ \\
\hline \multirow[t]{2}{*}{ Spatial Lag - specialisation } & & 0.003 & & 0.013 \\
\hline & & $(0.24)$ & & $(0.24)$ \\
\hline \multirow[t]{2}{*}{ Spatial Lag - dependent variable } & & & 0.035 & 0.035 \\
\hline & & & $(0.04)$ & $(0.04)$ \\
\hline Year fixed effects & $\mathrm{Y}$ & $\mathrm{Y}$ & $\mathrm{Y}$ & $\mathrm{Y}$ \\
\hline MAN area fixed effects & $\mathrm{Y}$ & $\mathrm{Y}$ & $\mathrm{Y}$ & $\mathrm{Y}$ \\
\hline $\mathrm{N}$ & 1910 & 1910 & 1910 & 1910 \\
\hline
\end{tabular}

Note: Models estimated as in previous specifications with the inclusion of spatially lagged variables. 
We also check the residuals from each of our main reported models for spatial autocorrelation. The Moran's I results and their associated p-values are reported in the supplementary material and indicate no significant spatial autocorrelation in almost all cases. Where we observe significant spatial autocorrelation in the residuals the magnitude of it is extremely small.

\subsection{Endogeneity of explanatory variables}

All explanatory variables are lagged by one period in all estimations, we also report the results of estimations with two-period lags. Further, we address potential endogeneity between new business establishments and the proportion of educational attainment and the unemployment rate, by re-running estimations keeping the 2002 level of these variables fixed. As these quantities do not change over time, they cannot possibly be responding to changes in the dependent variable. Again, the results are largely unchanged.

\subsection{Alternate panel specifications}

Finally the results of several alternative panel specifications are reported. As we have a considerable degree of over-dispersion in the data we employ a NB model with cluster-robust standard errors at the Urban Field level in our main sppecifications. A range of alternative NB/Poisson fixed effects, random effects and populationaveraged models with cluster-robust and bootstrapped standard errors are estimated. Results remain reasonably consistent across all specifications, and our reported results are somewhere towards the middle of the range for most variables.

\section{Discussion and concluding remarks}

This research examines the factors influencing new business establishments for both indigenous and foreign firms in Ireland over a period of significant infrastructural investment. The data spans a wide range of infrastructure, covers the introduction and recent history of broadband in Ireland, and captures a period in which $86 \%$ of the current motorway network was constructed. Complementing this is a rich dataset of other factors such as human capital and agglomeration measures.

The analysis does not include the Dublin City region, as this area is a uniquely attractive location for new firms in Ireland. We also do not consider areas below the 75th percentile of employment density. Given this, the analysis is an evaluation of how infrastructure roll-out affects regional towns and cities.

On average, the introduction of broadband in an area is associated with increased new firm counts. Other work such as Lehr et al. (2006) has also found this to be the case. Unusually for this literature, we are able to create detailed proxies for the availability of broadband provision. It is found that the availability of basic DSL 
has resulted in increased counts of both high and low-tech firms, while the benefits of middle-mile fibre appear to be concentrated in the high-tech sector. There is an additional effect in areas with greater competition in backhaul availability. The elasticity of new firm counts with respect to broadband is greater for foreign firms than for indigenous, but the marginal effect, in terms of increased new business establishments is smaller, as the rate of new foreign owned establishments is much lower than that of indigenous firms. Colombo et al. (2013) found that the adoption of basic broadband resulted in negligible productivity gains for Italian SMEs, while the benefits of advanced broadband are only realised if relevant to the firm's industry of operations. Given that many of the high-tech firms in our sample are involved in IT services, consultancy and component manufacture, it is likely that a complementarity exists between the adoption of high-speed broadband and their production processes.

Kandilov and Renkow (2010) find evidence of an urban bias when evaluating the impact of broadband on economic activity. Within different urban centres, Mack et al. (2011) finds quite a degree of heterogeneity in the elasticity of new firm counts with respect to broadband provision. It seems certain areas, perhaps related to industrial legacy or geography, have a greater capacity to absorb new technology in a productive manner. Indeed Mack and Faggian (2013) also find that broadband only provides productivity increases in areas with high levels of educational or attainment, or for high-skilled firms.

We add to this literature by examining how the interaction of broadband provision with educational attainment affects new firm formation. It appears the benefit of broadband, in terms of increased new businesses, is greater in areas with higher educational attainment, and may not be effective at encouraging new business at all below a certain threshold of educational attainment. The pre-existing level of human capital may be an important indicator of an area's ability to absorb new ICT technologies productively. This finding echoes previous work, such as Mack (2014), who cautions that while broadband is a key factor in dispersing knowledge intensive firms, it should not be viewed as the only factor.

Accessibility, measured by drive times, appears important to high-tech FDI, but less so for indigenous and low-tech firms, with the relative importance of proximity to airports almost twice that of proximity to motorway junctions. Similarly, Button et al. (1995) found that road and air links have a greater importance for inward investment than for domestic firms, and Mack et al. (2011) found proximity to airports to be important for knowledge-intensive firms.

Previous work, such as Holl (2004a) and Holl (2004b) found that large scale motorway investments in Portugal and Spain, respectively, resulted in a dispersal of manufacturing firms, with the benefits concentrated mostly near the new infrastructure. Given the level of motorway investment during our sample period, it is perhaps surprising that we do not observe a larger effect.

We find that diversity of skills in an area is more important for new business establishments than special- 
isation. This work is consistent with other research, such as Holl (2004b); Viladecans-Marsal (2004), Li et al. (2016) for high-growth firms and Barrios (2006) in an Irish context. This supports the "Nursery City" argument proposed by Duranton and Puga (2001), which suggests that diversity of skills is more important for start-ups, whereas specialisation is more important for subsequent employment growth. Diversified areas may act as a "nursery" for new firms in search of their ideal production processes, offsetting the comparatively lower production costs they might find in more specialised areas. In Ireland, more specialised areas tend to be lower skilled and rural in which agriculture dominates, consistent with our results.

The local unemployment rate has a positive and significant effect on new business establishments for FDI and the high-tech sector, consistent with Coughlin et al. (1991), perhaps suggesting an effect of greater labour availability.

Proximity to third level institutions is highly significant for all firm-types, with the exception of low-tech FDI. The level of educational attainment is important for firms of all types, but particularly those in high-tech sectors. Previous work such as Akerman et al. (2015) has pointed to a skill complementarity between broadband adoption and skilled-labour. Broadband can increase the productivity of skilled graduates, particularly in scientific and technical disciplines, but can act as a substitute for less educated workers, lowering their marginal productivity.

Our results have wider implications for regional development policy and universal service provision. Decisions regarding the provision of distinct infrastructures are rarely taken together, or considered along with other factors, such as healthcare provision or education. This is perhaps due to particular government departments having authority over certain areas, and not others. An objective of policymakers within each department might be to ensure a minimum level of infrastructure provision in their particular domain. This focus on a comprehensive roll-out of one service in particular may be suboptimal. If there are complementarities between infrastructure and other local factors the optimal pattern of deployment (and public subsidies or cross-subsidies) requires a broader consideration ${ }^{18}$.

Newbery (2012) argues that if suboptimal infrastructure investment constrains other investment, it can constrain growth, while excessive investment has no added value. This is important for regional policy, as simply investing in broadband infrastructure in a structurally weak region may be insufficient to stimulate development if this region has a low level of human capital. For such a region a more appropriate approach would be to complement the investment in broadband with measures to improve human capital.

\footnotetext{
${ }^{18}$ Crescenzi et al. (2016) also point to the importance of government quality in determining the return to transport infrastructure investment.
} 


\section{References}

Akerman, A., Gaarder, I., and Mogstad, M. (2015). The skill complementarity of broadband internet. Technical report, National Bureau of Economic Research.

Alama-Sabater, L., Artal-Tur, A., and Navarro-Azorinn, J. M. (2010). Industrial location, spatial discrete choice models and the need to account for neighbourhood effects. The Annals of Regional Science, 47(2):393-418.

Alañón-Pardo, Á. and Arauzo-Carod, J.-M. (2013). Agglomeration, accessibility and industrial location: evidence from Spain. Entrepreneurship 63 Regional Development, 25(3-4):135-173.

Armington, C. and Acs, Z. J. (2002). The determinants of regional variation in new firm formation. Regional Studies, 36(1):33-45.

Artz, G. M., Kim, Y., and Orazem, P. F. (2015). Does agglomeration matter everywhere?: New firm location decisions in rural and urban markets*. Journal of Regional Science, 56(1):72-95.

Audretsch, D. B., Heger, D., and Veith, T. (2015). Infrastructure and entrepreneurship. Small Business Economics, 44(2):219-230.

Audretsch, D. B., Lehmann, E. E., and Warning, S. (2005). University spillovers and new firm location. Research Policy, 34(7):1113-1122.

Barrios, S. (2006). Multinationals' location choice, agglomeration economies, and public incentives. International Regional Science Review, 29(1):81-107.

Bhat, C. R., Paleti, R., and Singh, P. (2014). A spatial multivariate count model for Firm location decisions. Journal of Regional Science, pages 462-502.

Boarnet, M. G. (1998). Spillovers and the locational effects of public infrastructure. Journal of Regional Science, 38(3):381-400.

Button, K. J., Leitham, S., McQuaid, R. W., and Nelson, J. D. (1995). Transport and industrial and commercial location. The Annals of Regional Science, 29(2):189-206.

Cameron, A. C. and Trivedi, P. K. (2013). Regression analysis of count data, volume 53. Cambridge University Press.

Carlton, D. W. (1983). The location and employment choices of new firms: An econometric model with discrete and continuous endogenous variables. The Review of Economics and Statistics, pages 440-449. 
Colombo, M. G., Croce, A., and Grilli, L. (2013). ICT services and small businesses productivity gains: An analysis of the adoption of broadband internet technology. Information Economics and Policy, 25(3):171-189.

Coughlin, C. C., Terza, J. V., and Arromdee, V. (1991). State characteristics and the location of foreign direct investment within the United States. The Review of Economics and Statistics, 73(4):675.

Crescenzi, R., Di Cataldo, M., and Rodríguez-Pose, A. (2016). Government quality and the economic returns of transport infrastructure investment in european regions. Journal of Regional Science, 56(4):555-582.

CSO (2013). Central Statistics Office: Information Society Statistics Enterprises. Downloaded 14 February 2015. Available at: www.cso.ie.

David, H., Levy, F., and Murnane, R. J. (2003). The skill content of recent technological change: An empirical exploration. Quarterly Journal of Economics, 118(4).

Devereux, M. P., Griffith, R., and Simpson, H. (2007). Firm location decisions, regional grants and agglomeration externalities. Journal of Public Economics, 91(3-4):413-435.

Duranton, G. and Puga, D. (2001). Nursery cities: Urban diversity, process innovation, and the life cycle of products. American Economic Review, pages 1454-1477.

Elhorst, J. P. (2012). Matlab software for spatial panels. International Regional Science Review, 37(3):389-405.

Feldman, M. P. and Audretsch, D. B. (1999). Innovation in cities: Science-based diversity, specialization and localized competition. European Economic Review, 43(2):409-429.

Garcia-López, M.-À., Hémet, C., and Viladecans-Marsal, E. (2017). How does transportation shape intrametropolitan growth? an answer from the regional express rail. Journal of Regional Science.

Gillet, S., Lehr, W., and Sirbu, M. (2006). Measuring broadbands economic impact. Final report.

Guimaraes, P., Figueirdo, O., and Woodward, D. (2003). A tractable approach to the firm location decision problem. Review of Economics and Statistics, 85(1):201-204.

Guimaraes, P., Figueiredo, O., and Woodward, D. (2004). Industrial location modeling: Extending the random utility framework. Journal of Regional Science, 44(1):1-20.

Halleck Vega, S. and Elhorst, J. P. (2015). The slx model. Journal of Regional Science, 55(3):339-363.

Haller, S. A. and Lyons, S. (2015). Broadband adoption and firm productivity: Evidence from Irish manufacturing firms. Telecommunications Policy, 39(1):1-13. 
Hidalgo Perez, M. A., O'Kean Alonso, J. M., and Rodriguez Lopez, J. (2016). Labor demand and ICT adoption in Spain. Telecommunications Policy, 40(5):450-470.

Holl, A. (2004a). Manufacturing location and impacts of road transport infrastructure: Empirical evidence from Spain. Regional Science and Urban Economics, 34(3):341-363.

Holl, A. (2004b). Transport infrastructure, agglomeration economies, and firm birth: Empirical evidence from Portugal. Journal of Regional Science, 44(4):693-712.

Jofre-Monseny, J., Marin-Lopez, R., and Viladecans-Marsal, E. (2011). The mechanisms of agglomeration: Evidence from the effect of inter-industry relations on the location of new firms. Journal of Urban Economics, 70(2-3):61-74.

Kandilov, I. T. and Renkow, M. (2010). Infrastructure investment and rural economic development: An evaluation of USDAs broadband loan program. Growth and Change, 41(2):165-191.

Kim, Y. and Orazem, P. F. (2017). Broadband internet and new firm location decisions in rural areas. American Journal of Agricultural Economics, 99(1):285-302.

Kolko, J. (2012). Broadband and local growth. Journal of Urban Economics, 71(1):100-113.

Lawless, M. (2012). Job creation and destruction in recession. Central Bank of Ireland, Economic Letter Series, 1.

Lehr, W. H., Osorio, C., Gillett, S. E., and Sirbu, M. A. (2006). Measuring broadbands economic impact.

Li, M., Goetz, S. J., Partridge, M., and Fleming, D. A. (2016). Location determinants of high-growth firms. Entrepreneurship \& Regional Development, 28(1-2):97-125.

Mack, E. and Faggian, A. (2013). Productivity and broadband: The human factor. International Regional Science Review, 36(3):392-423.

Mack, E. A. (2014). Broadband and knowledge intensive firm clusters: Essential link or auxiliary connection? Papers in Regional Science, 93(1):3-29.

Mack, E. A., Anselin, L., and Grubesic, T. H. (2011). The importance of broadband provision to knowledge intensive firm location. Regional Science Policy $\& 3$ Practice, 3(1):17-35.

Mack, E. A. and Grubesic, T. H. (2009). Broadband provision and firm location in ohio: An exploratory spatial analysis. Tijdschrift voor economische en sociale geografie, 100(3):298-315. 
Mack, E. A. and Rey, S. J. (2014). An econometric approach for evaluating the linkages between broadband and knowledge intensive firms. Telecommunications Policy, 38(1):105-118.

McFadden, D. et al. (1973). Conditional logit analysis of qualitative choice behavior.

McHenry, P. (2014). The geographic distribution of human capital: Measurement of contributing mechanisms. Journal of Regional Science, 54(2):215-248.

Newbery, D. (2012). Energy and infrastructure. Submission to the LSE Growth Commission, available at http://tinyurl. com/c8qtahl.

Percoco, M. (2015). Highways, local economic structure and urban development. Journal of Economic Geography, page lbv031.

Pusterla, F. and Resmini, L. (2007). Where do foreign firms locate in transition countries? An empirical investigation. The Annals of Regional Science, 41(4):835-856.

RedC (2013). ComReg Business ICT Survey. Downloaded 14 February 2015. Available at: www.comreg.ie.

Schmidheiny, K. and Brulhart, M. (2011). On the equivalence of location choice models: Conditional logit, nested logit and Poisson. Journal of Urban Economics, 69(2):214-222.

Siedschlag, I., Zhang, X., and Smith, D. (2013). What determines the location choice of multinational firms in the information and communication technologies sector? Economics of Innovation and New Technology, $22(6): 581-600$.

Taylor, R. D. and Schejter, A. M. (2013). Beyond Broadband Access: Developing Data-based Information Policy Strategies. Fordham Univ Press.

Van Gaasbeck, K. A. (2008). A rising tide: Measuring the economic effects of broadband use across California. The Social Science Journal, 45(4):691-699.

Viladecans-Marsal, E. (2004). Agglomeration economies and industrial location: city-level evidence. Journal of Economic Geography, 4(5):565-582.

Zucker, L. G., Darby, M. R., and Brewer, M. B. (1998). Intellectual human capital and the birth of US biotechnology enterprises. American Economic Review, pages 290-306. 


\section{Supporting Information}

Additional supporting information may be found in the online version of this article at the publishers web site.

- A: Data

- B: Additional analysis

- C: Results of robustness tests 


\section{$1 \quad$ Appendix}

\section{A Data}

\section{A.1 Unit of analysis: "Urban Fields"}

We create new units of analysis which we will refer to as "Urban Fields". These areas are either single Electoral Divisions (EDs) or are aggregations of contiguous EDs which are at or above the 75th percentile of employment density, based on the 2011 Census Place of Work School or College (POWSCAR) and merged using GIS software ${ }^{1}$.

As discussed in the previous section, our Urban Field unit of aggregation yields a number of benefits in terms of reducing the potential for spatial dependence as generally speaking, contiguous EDs with a sufficiently high employment density are considered part of the same Urban Field. The exception to this is on the east coast, highlighted in Fig. 1.

We define the Dublin City Urban Field as those EDs that broadly map onto Dublin postcode regions, as highlighted in red in Fig. 1. This area is omitted from all estimations as this is a uniquely attractive area for new firms and very different from the rest of the country in terms of population and employment density, infrastructure and general accessibility.

\section{A.2 Dependent variables: Sources and descriptive statistics}

The number of firms by year of entry is shown in Table A1. There is a noticeable drop off of new firms in 2010 and 2011. We can see that this is entirely driven by domestic firms; it probably reflects the severe recession affecting Ireland after 2008. We control for time-specific trends in all estimations.

\footnotetext{
${ }^{1}$ Detail on the relevant EDs and corresponding Urban Fields are available on request. There are approximately 3400 EDs in Ireland.
} 


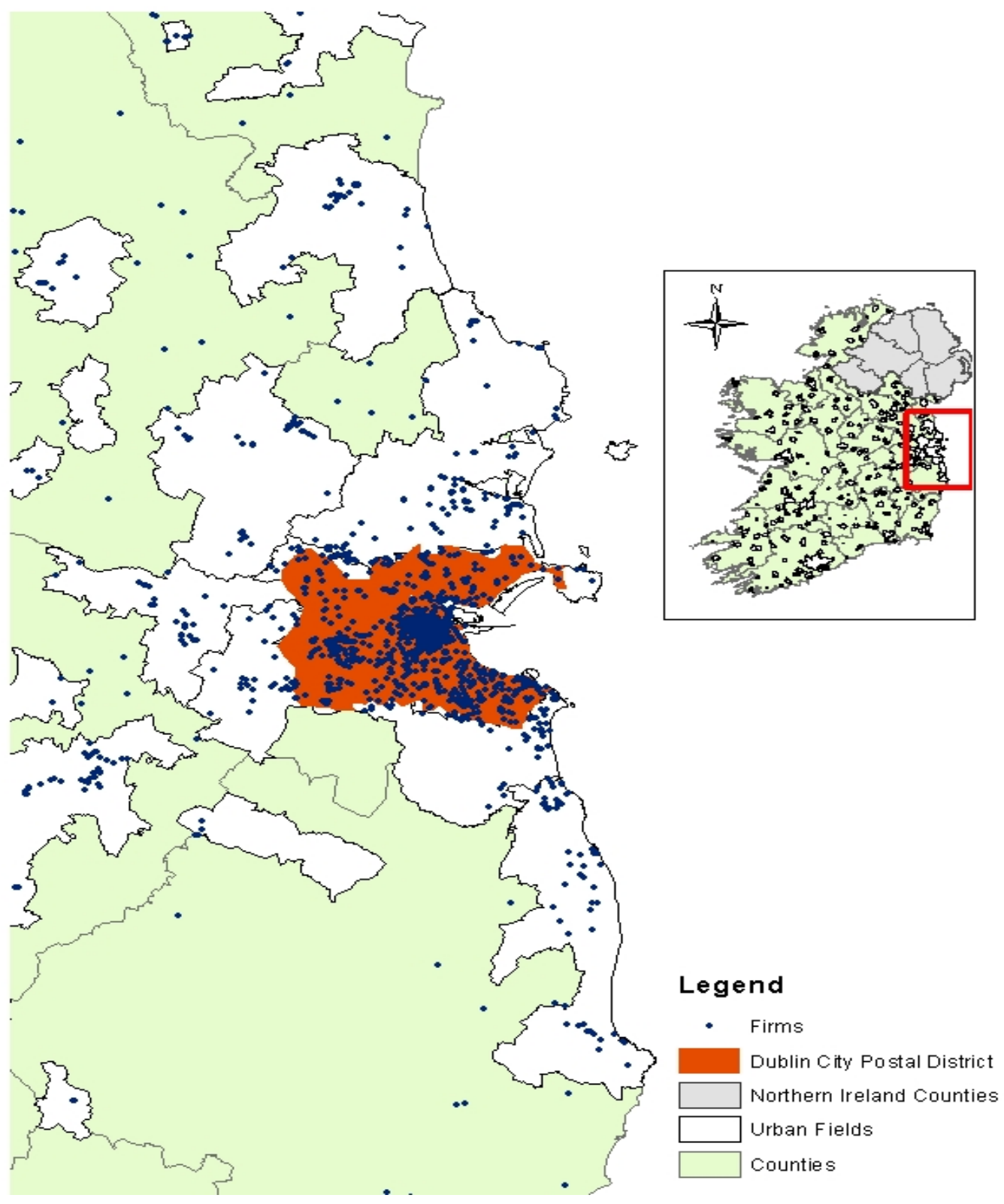

Figure 1: Map of East Coast Urban Fields 
Table A1: New firms by year of entry

\begin{tabular}{lccccccccccc}
\hline Firm type & 2002 & 2003 & 2004 & 2005 & 2006 & 2007 & 2008 & 2009 & 2010 & 2011 & Total \\
\hline Foreign firms & 30 & 22 & 20 & 21 & 18 & 23 & 15 & 21 & 19 & 28 & 217 \\
Domestic firms & 148 & 169 & 219 & 182 & 241 & 171 & 221 & 221 & 113 & 82 & 1767 \\
\hline Total & 178 & 191 & 239 & 203 & 259 & 194 & 236 & 242 & 132 & 110 & 1984 \\
\hline
\end{tabular}


The new foreign firms are concentrated in the major urban centres and along the main motorway arteries, as illustrated in Fig. 2. A very small proportion of firms go to areas other than the greater Dublin area, Cork, Galway, Limerick and Waterford. These clusters are also apparent for domestic firms, however there is a much greater degree of geographic dispersal. Foreign firms are generally larger and more knowledge intensive; we would expect these firms to favour urban areas to avail of agglomeration economies and better infrastructure. Domestic firms - particularly small ones - may locate in areas in which their owners reside, so the count of new domestic firms may partly reflect the extent of entrepreneurial activity in an area. 
Foreign Firms

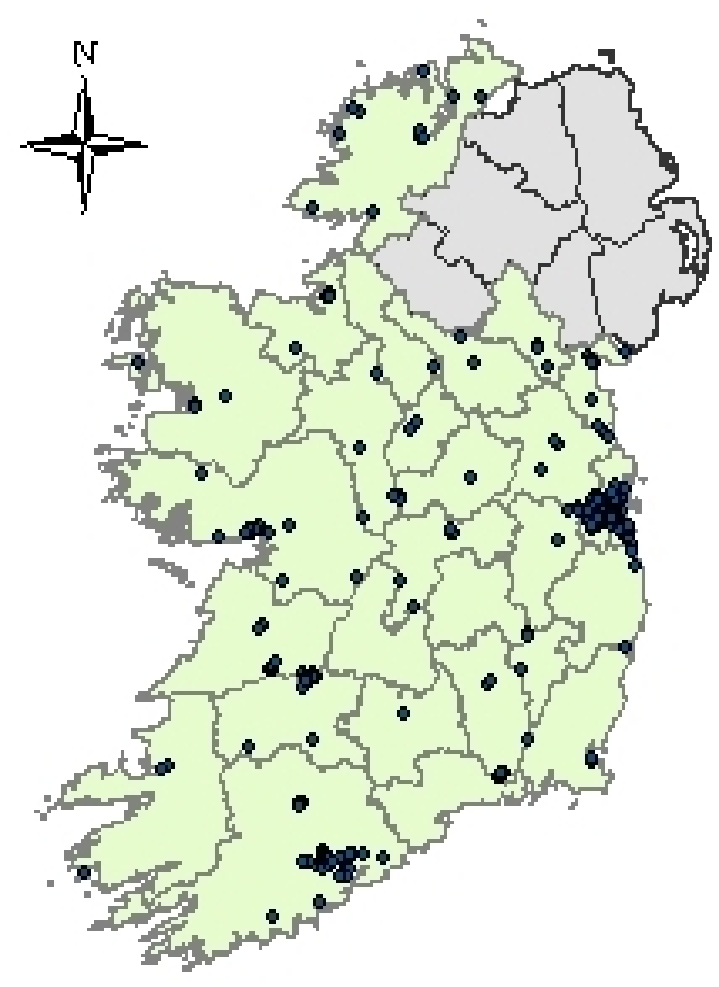

\section{Domestic Firms}

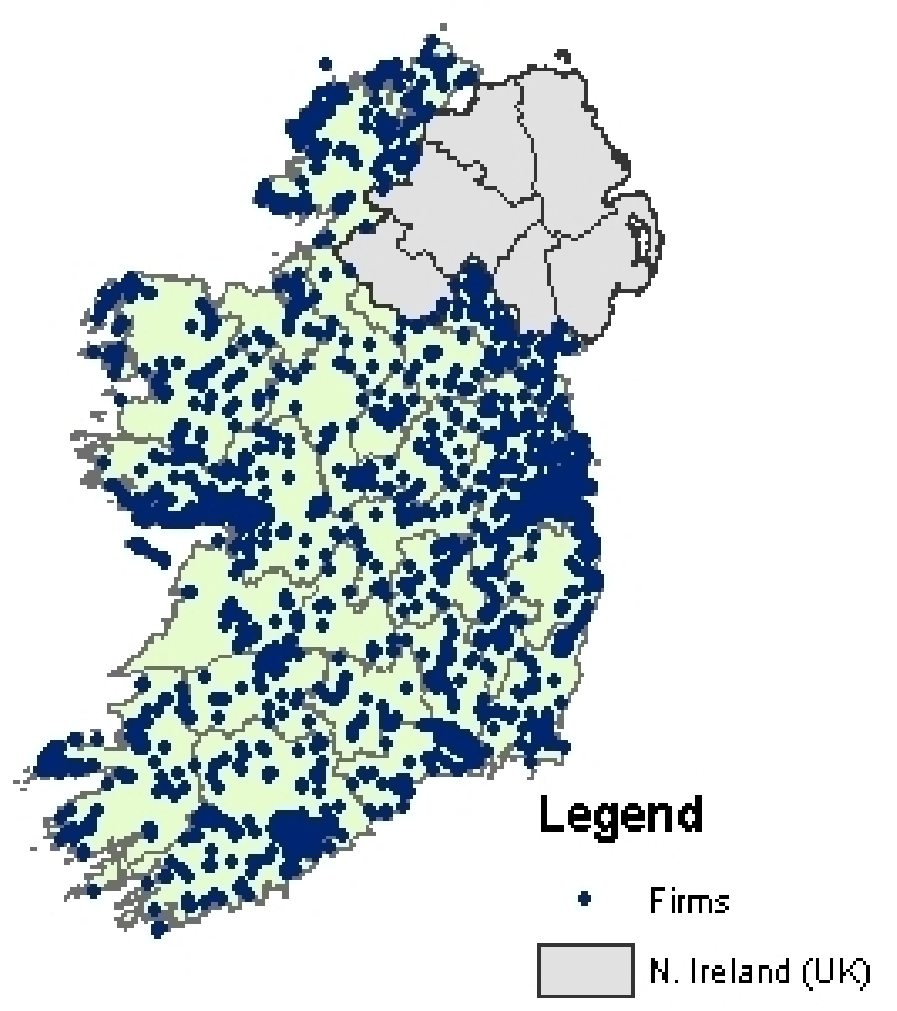

Figure 2: Location of new firms 2002-2011 
Table A2: Dependent Variables: Firm counts

\begin{tabular}{lccccc}
\hline Type of Firm & Obs & Mean & Std. Dev. & Min & Max \\
\hline Foreign & 1910 & 0.11 & 0.58 & 0 & 8 \\
Domestic & 1910 & 0.90 & 2.95 & 0 & 47 \\
High-tech & 1910 & 0.67 & 2.58 & 0 & 43 \\
Low-tech & 1910 & 0.32 & 0.92 & 0 & 11 \\
Financial & 1910 & 0.02 & 0.18 & 0 & 4 \\
Foreign high-tech & 1910 & 0.09 & 0.48 & 0 & 7 \\
Domestic high-tech & 1910 & 0.58 & 2.24 & 0 & 39 \\
Foreign Low-tech & 1910 & 0.02 & 0.14 & 0 & 3 \\
Domestic Low-tech & 1910 & 0.31 & 0.89 & 0 & 11 \\
\hline
\end{tabular}




\section{A.3 Explanatory variables: Descriptive statistics}

Table A3: Descriptive statistics for main explanatory variables

\begin{tabular}{|c|c|c|c|c|c|c|}
\hline Variable Type & Variable & Obs & Mean & Std. Dev. & Min & Max \\
\hline \multirow[t]{4}{*}{ Broadband } & MAN-area dummy & 1910 & 0.372 & 0.483 & 0 & 1 \\
\hline & MAN & 1910 & 0.062 & 0.242 & 0 & 1 \\
\hline & MAN with BT backhaul & 1910 & 0.047 & 0.211 & 0 & 1 \\
\hline & Eircom enabled exchange dummy & 1910 & 0.739 & 0.439 & 0 & 1 \\
\hline \multirow[t]{5}{*}{ Accessibility } & Motorway & 1910 & 51.633 & 41.121 & 2.40 & 250.07 \\
\hline & Airport & 1910 & 56.321 & 21.674 & 8.22 & 104.47 \\
\hline & Train Station & 1910 & 21.300 & 16.358 & 1.57 & 82.28 \\
\hline & University & 1910 & 116.208 & 64.990 & 13.45 & 355.35 \\
\hline & IT & 1910 & 63.732 & 28.310 & 5.51 & 181.10 \\
\hline \multirow[t]{3}{*}{ Labour Force } & Relative Employment compensation & 1910 & 0.911 & 0.103 & 0.73 & 1.18 \\
\hline & Unemployment rate & 1910 & 0.114 & 0.055 & 0.04 & 0.39 \\
\hline & Total Employment & 1910 & 0.991 & 2.697 & 0 & 29.66 \\
\hline
\end{tabular}


Table A4: Descriptive statistics for agglomeration variables

\begin{tabular}{lccccc}
\hline Agglomeration Measure & Obs & Mean & Std. Dev. & Min & Max \\
\hline Specialisation & 1910 & 0.556 & 0.268 & 0 & 1 \\
Total Employment Foreign & 1910 & 542.080 & 1820.260 & 0 & 20097 \\
Foreign share of employment & 1910 & 0.259 & 0.320 & 0 & 1 \\
Foreign density of employment & 1910 & 0.096 & 0.195 & 0 & 1.831 \\
Total Employment Irish & 1910 & 448.814 & 954.849 & 0 & 10124 \\
Irish share of employment & 1910 & 0.679 & 0.358 & 0 & 1 \\
Irish density of employment & 1910 & 0.138 & 0.210 & 0 & 1.743 \\
High-tech share of employment & 1910 & 0.271 & 0.305 & 0 & 1 \\
High-tech density of employment & 1910 & 0.078 & 0.136 & 0 & 0.885 \\
Low-tech share of employment & 1910 & 0.655 & 0.349 & 0 & 1 \\
Low-tech density of employment & 1910 & 0.153 & 0.244 & 0 & 2.493 \\
Services share of employment & 1910 & 0.111 & 0.200 & 0 & 1 \\
Services density of employment & 1910 & 0.031 & 0.085 & 0 & 1.267 \\
Financial share of employment & 1910 & 0.011 & 0.072 & 0 & 1 \\
Financial density of employment & 1910 & 0.003 & 0.020 & 0 & 0.216 \\
\hline
\end{tabular}


A.4 DSL roll-out over time by region

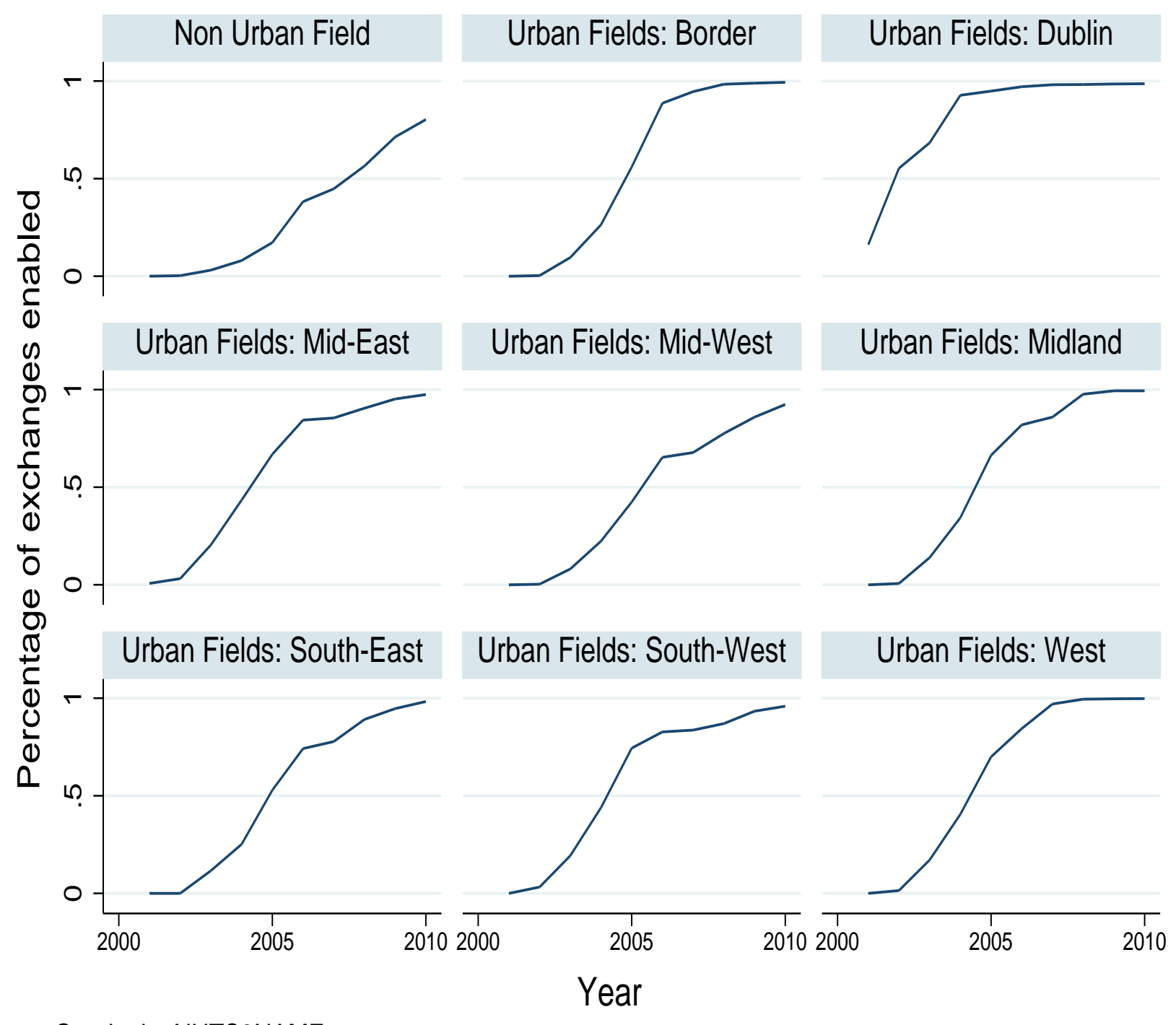

Graphs by NUTS3NAME

Figure 3: Share of enabled exchanges for DSL over time in Urban Fields by NUTS3 regions 


\section{B Additional analysis}

The following estimations examine the effect of ICT over different points in time. These results are confined to the supplementary material, as low rates of new entrants for certain splits make it more difficult to establish robust estimates.

\section{B.1 The effect of ICT over time}

The rationale for deploying ICT in some places rather than others is driven by economies of density (i.e. existing customers) rather than the expectation that firms are more likely to enter in such places. However, it might take time for deployment to reach its full effects. This section seeks to disentangle the baseline deployment effect of broadband from the length of time since initial deployment. We create a categorical variable to account for the time since deployment of ICT in each area $\left(I C T_{0}=\right.$ No ICT, $I C T_{13}=$ ICT in place for 1-3 years, $I C T_{4}=$ ICT in place for 4 or more years). This choice of time intervals is informed by Lyons (2014) who found that residential use of DSL took time to ramp up after enabling and converged to the average for existing enabled areas after about four years.

The results in Table. B1 demonstrate that there is an initial deployment effect for DSL, and this effect increases for later periods. This effect is significant for all firm types except FDI. The results for middle-mile fibre are significant in both periods for foreign and high-tech firms. While the effect is slightly larger in the initial period, the magnitude of the coefficients remains quite stable over time. 
Table B1: Effect of time since deployment of ICT on firm formation

\begin{tabular}{lcccc}
\hline & \multicolumn{2}{c}{ All Firms } & \multicolumn{2}{c}{ All Firms } \\
Variable & Foreign & Domestic & High-tech & Low-tech \\
\hline No DSL & {$[$ Ref $]$} & {$[$ Ref $]$} & {$[$ Ref $]$} & {$[$ Ref $]$} \\
& - & - & - & - \\
DSL (1-3) years & 0.021 & $0.645^{* * *}$ & $0.682^{* * *}$ & $0.142^{* * *}$ \\
& $(0.060)$ & $(0.194)$ & $(0.159)$ & $(0.051)$ \\
DSL (4+) years & 0.080 & $1.179^{* * *}$ & $0.833^{* * *}$ & $0.471^{* * *}$ \\
& $(0.131)$ & $(0.368)$ & $(0.264)$ & $(0.151)$ \\
\hline No MAN & {$[$ Ref $]$} & {$[$ Ref $]$} & {$[R e f]$} & {$[R e f]$} \\
& - & - & - & - \\
MAN (1-3) years & $0.105^{* *}$ & 0.182 & $0.456^{* * *}$ & -0.104 \\
& $(0.051)$ & $(0.170)$ & $(0.138)$ & $(0.067)$ \\
MAN (4+) years & $0.089^{*}$ & 0.427 & $0.447^{* *}$ & 0.039 \\
& $(0.052)$ & $(0.304)$ & $(0.220)$ & $(0.088)$ \\
\hline Year fixed effects & Y & Y & Y & Y \\
MAN area fixed effects & Y & Y & Y & Y \\
\hline
\end{tabular}




\section{B.2 The effect of ICT during boom and bust}

Ireland experienced an extreme economic expansion and contraction during our period of analysis. We control for annual trends using year fixed effects, however the effect of deployment may differ depending on which period is examined. To test this we split the sample into two periods: up to and including 2008 (Table. B2); 2009 and after (Table. B3).

The effect of DSL remains broadly consistent across both periods for all types of firm. The effect of the MANs is larger for domestic and high-tech firms in the pre-crash period, but larger for foreign firms in the post-crash period. Interestingly, the effect of the MANs was not observed for domestic firms in the main set of estimations, indicating that the overall reduction in new domestic firms in the post-crash period was masking a positive and significant effect in the earlier period. 
Table B2: Effect of ICT on firm formation 2008 and before

\begin{tabular}{lcccc}
\hline & \multicolumn{2}{c}{ All Firms } & \multicolumn{2}{c}{ All Firms } \\
Variable & Foreign & Domestic & High-tech & Low-tech \\
\hline 1.Eircom DSL & $0.059^{* *}$ & $0.817^{* * *}$ & $0.679^{* * *}$ & $0.174^{* * *}$ \\
& $(0.03)$ & $(0.24)$ & $(0.12)$ & $(0.07)$ \\
1.MAN effect dummy & $0.102^{* *}$ & $0.578^{*}$ & $0.737^{* * *}$ & -0.027 \\
& $(0.04)$ & $(0.30)$ & $(0.28)$ & $(0.09)$ \\
1.MAN increased backhaul & - & - & $0.756^{* *}$ & - \\
& - & - & $(0.38)$ & - \\
\hline Year fixed effects & $\mathrm{Y}$ & $\mathrm{Y}$ & $\mathrm{Y}$ & $\mathrm{Y}$ \\
MAN area fixed effects & $\mathrm{Y}$ & $\mathrm{Y}$ & $\mathrm{Y}$ & $\mathrm{Y}$ \\
\hline
\end{tabular}


Table B3: Effect of ICT on firm formation post 2008

\begin{tabular}{lcccc}
\hline & \multicolumn{2}{c}{ All Firms } & \multicolumn{2}{c}{ All Firms } \\
Variable & Foreign & Domestic & High-tech & Low-tech \\
\hline 1.Eircom DSL & $0.138^{* * *}$ & $0.833^{* * *}$ & $0.539^{* * *}$ & $0.206^{* * *}$ \\
& $(0.02)$ & $(0.32)$ & $(0.11)$ & $(0.04)$ \\
1.MAN effect dummy & $0.170^{* * *}$ & -0.002 & -0.26 & -0.041 \\
& $(0.06)$ & $(0.24)$ & $(0.17)$ & $(0.08)$ \\
1.MAN increased backhaul & - & - & $0.283^{* *}$ & - \\
& - & - & $(0.13)$ & - \\
\hline Year fixed effects & $\mathrm{Y}$ & $\mathrm{Y}$ & $\mathrm{Y}$ & $\mathrm{Y}$ \\
MAN area fixed effects & $\mathrm{Y}$ & $\mathrm{Y}$ & $\mathrm{Y}$ & $\mathrm{Y}$ \\
\hline
\end{tabular}




\section{Results of robustness tests}

Table C1: Comparison of high-tech firm counts from alternative model specifications

\begin{tabular}{|c|c|c|c|c|c|c|c|c|c|c|c|c|}
\hline \multirow[b]{2}{*}{ Variable } & \multirow{2}{*}{$\begin{array}{c}\text { Reported results } \\
\text { NB, PA } \\
\text { vce(robust) }\end{array}$} & \multicolumn{6}{|c|}{ Alternative panel specifications } & \multicolumn{2}{|c|}{ Zero-inflated models } & \multicolumn{3}{|c|}{ Alternate lagged models } \\
\hline & & $\begin{array}{c}\text { NB, RE } \\
\text { ve(boot) }\end{array}$ & $\begin{array}{l}\text { Poisson, PA } \\
\text { ve(robust) }\end{array}$ & $\begin{array}{c}\text { Poisson, RE } \\
\text { vce(robust) }\end{array}$ & $\begin{array}{l}\text { Poisson, RE } \\
\text { vce(boot) }\end{array}$ & $\begin{array}{l}\text { Poisson, } \mathrm{FE} \\
\text { vce(robust) }\end{array}$ & $\begin{array}{c}\mathrm{NB}, \mathrm{FE} \\
\text { vce (robust) }\end{array}$ & $\begin{array}{c}\text { Poisson, } \\
\text { vce(robust) }\end{array}$ & $\begin{array}{c}\mathrm{NB}, \\
\text { vce(robust) }\end{array}$ & $\begin{array}{c}\text { Third-level } \\
(2002)\end{array}$ & $\begin{array}{c}\text { Unemployment } \\
(2002)\end{array}$ & All $x$ t-2 \\
\hline \multirow[t]{2}{*}{ 1.Eircom DSL enabled exchange } & $0.531^{* * *}$ & $0.780^{* * *}$ & $0.391^{* * *}$ & $0.698^{*}$ & $0.698^{* * *}$ & 0.296 & $0.338^{*}$ & $0.351^{* * *}$ & $0.346 * * *$ & $0.519^{* * *}$ & $0.530^{* * *}$ & 0.173 \\
\hline & $(0.10)$ & $(0.20)$ & $(0.06)$ & $(0.40)$ & $(0.16)$ & $(0.19)$ & $(0.21)$ & $(0.07)$ & $(0.08)$ & $(0.11)$ & $(0.10)$ & $(0.12)$ \\
\hline \multirow[t]{2}{*}{ 1.MAN effect } & $0.422^{* *}$ & 0.358 & $0.372^{*}$ & 0.359 & 0.359 & 0.242 & $0.295^{*}$ & 0.232 & $0.278^{*}$ & $0.466^{* *}$ & $0.388 * *$ & $0.341^{*}$ \\
\hline & $(0.19)$ & $(0.23)$ & $(0.21)$ & $(0.23)$ & $(0.24)$ & $(0.23)$ & $(0.16)$ & $(0.17)$ & $(0.15)$ & $(0.21)$ & $(0.19)$ & $(0.20)$ \\
\hline \multirow[t]{2}{*}{ 1. MAN with increased backhaul } & $0.683^{* * *}$ & $0.600^{* * *}$ & $0.618^{* * *}$ & $0.592 * * *$ & $0.592 * * *$ & $0.421^{* * *}$ & $0.385 * *$ & $0.486 * * *$ & 0.386 *** & $0.711^{* * *}$ & $0.606 * * *$ & 0.596 ** \\
\hline & $(0.24)$ & $(0.16)$ & $(0.15)$ & $(0.16)$ & $(0.13)$ & $(0.14)$ & $(0.16)$ & $(0.15)$ & $(0.13)$ & $(0.24)$ & $(0.23)$ & $(0.26)$ \\
\hline \multirow[t]{2}{*}{ Motorway } & 0.055 & 0 & 0.006 & -0.021 & -0.021 & -0.103 & -0.076 & -0.005 & 0.025 & 0.069 & 0.044 & 0.068 \\
\hline & $(0.05)$ & $(0.06)$ & $(0.05)$ & $(0.07)$ & $(0.06)$ & $(0.07)$ & $(0.09)$ & $(0.05)$ & $(0.05)$ & $(0.06)$ & $(0.06)$ & $(0.06)$ \\
\hline \multirow[t]{2}{*}{ Airport } & 0.118 & 0.132 & $0.193^{*}$ & 0.161 & 0.161 & & & 0.172 & 0.101 & 0.113 & 0.138 & 0.078 \\
\hline & $(0.17)$ & $(0.18)$ & $(0.11)$ & $(0.27)$ & $(0.18)$ & & & $(0.11)$ & $(0.12)$ & $(0.18)$ & $(0.17)$ & $(0.18)$ \\
\hline \multirow[t]{2}{*}{ Train Station } & 0.051 & 0.039 & $0.087^{* *}$ & 0.064 & 0.064 & & & $0.081^{*}$ & 0.058 & 0.056 & 0.048 & 0.092 \\
\hline & $(0.06)$ & $(0.08)$ & $(0.04)$ & $(0.09)$ & $(0.07)$ & & & $(0.05)$ & $(0.05)$ & $(0.06)$ & $(0.06)$ & $(0.07)$ \\
\hline \multirow[t]{2}{*}{ Urbanisation (diversity of employment) } & $-0.448^{* * *}$ & $-1.024^{* * *}$ & $-0.506^{* * *}$ & -0.98 & $-0.980^{* * *}$ & $0.580^{*}$ & 0.508 & $-0.463^{* * *}$ & $-0.499 * * *$ & $-0.426^{* * *}$ & $-0.437 * * *$ & $-0.542^{* * *}$ \\
\hline & $(0.10)$ & $(0.27)$ & $(0.08)$ & $(0.63)$ & $(0.23)$ & $(0.32)$ & $(0.33)$ & $(0.09)$ & $(0.12)$ & $(0.10)$ & $(0.10)$ & $(0.10)$ \\
\hline \multirow[t]{2}{*}{ Sector share of employment } & 0.116 & 0.117 & 0.107 & 0.092 & 0.092 & 0.051 & 0.107 & 0.056 & 0.026 & 0.13 & 0.122 & 0.264 \\
\hline & $(0.15)$ & $(0.10)$ & $(0.10)$ & $(0.11)$ & $(0.13)$ & $(0.28)$ & $(0.27)$ & $(0.09)$ & $(0.11)$ & $(0.15)$ & $(0.16)$ & $(0.17)$ \\
\hline \multirow[t]{2}{*}{ Sector density of employment } & 0.082 & -0.005 & 0.037 & -0.011 & -0.011 & -0.207 & $-0.268^{*}$ & -0.027 & -0.011 & 0.029 & 0.107 & 0.038 \\
\hline & $(0.17)$ & $(0.07)$ & $(0.11)$ & $(0.10)$ & $(0.10)$ & $(0.15)$ & $(0.15)$ & $(0.09)$ & $(0.12)$ & $(0.16)$ & $(0.20)$ & $(0.19)$ \\
\hline \multirow[t]{2}{*}{ Total employment in island } & $1.186^{* *}$ & $0.081^{*}$ & $0.430^{* * * *}$ & 0.077 & 0.077 & -0.041 & 0.007 & $0.508 * * *$ & $0.706 * * *$ & $1.262^{*}$ & $1.174^{*}$ & $1.353^{*}$ \\
\hline & $(0.60)$ & $(0.04)$ & $(0.09)$ & $(0.08)$ & $(0.06)$ & $(0.06)$ & $(0.07)$ & $(0.10)$ & $(0.22)$ & $(0.65)$ & $(0.61)$ & $(0.72)$ \\
\hline \multirow[t]{2}{*}{ Inv distance to nearest TL institute } & $0.314^{* * *}$ & $0.165^{* *}$ & $0.216^{* * *}$ & 0.222 & $0.222^{* *}$ & & & $0.101^{*}$ & $0.189 * * *$ & $0.326^{* * *}$ & $0.287^{* *}$ & $0.342^{* * *}$ \\
\hline & $(0.12)$ & $(0.07)$ & $(0.07)$ & $(0.22)$ & $(0.10)$ & & & $(0.06)$ & $(0.07)$ & $(0.12)$ & $(0.12)$ & $(0.13)$ \\
\hline \multirow[t]{2}{*}{ Pop prop with third level qual } & $3.096 * * *$ & $2.613^{* * *}$ & $2.606^{* * *}$ & $2.580^{* * *}$ & $2.580^{* * *}$ & 0.189 & 0.368 & $2.357^{* * *}$ & $2.469^{* * *}$ & & $3.369^{* * *}$ & $3.388 * * *$ \\
\hline & $(0.64)$ & $(0.43)$ & $(0.25)$ & $(0.53)$ & $(0.45)$ & $(1.02)$ & $(1.09)$ & $(0.24)$ & $(0.33)$ & & $(0.68)$ & $(0.73)$ \\
\hline \multirow[t]{2}{*}{ Relative employment comp (county) } & 0.509 & 1.045 & $1.207^{*}$ & 1.17 & 1.17 & 1.496 & 1.519 & $1.114^{*}$ & 0.614 & 0.574 & 0.524 & -0.062 \\
\hline & $(0.74)$ & $(1.04)$ & $(0.62)$ & (1.19) & (1.17) & (1.46) & (1.53) & $(0.57)$ & $(0.60)$ & $(0.75)$ & $(0.76)$ & $(0.72)$ \\
\hline \multirow[t]{2}{*}{ Unemployment } & $0.530^{* * *}$ & $0.721^{* *}$ & $0.548^{* * *}$ & 0.616 & $0.616^{*}$ & -0.396 & -0.543 & $0.554^{* * *}$ & $0.633^{* * *}$ & $0.484^{* *}$ & & $0.545^{* *}$ \\
\hline & $(0.20)$ & $(0.32)$ & $(0.15)$ & $(0.89)$ & $(0.33)$ & $(0.38)$ & $(0.44)$ & $(0.18)$ & $(0.21)$ & $(0.20)$ & & $(0.23)$ \\
\hline Pop prop with third level qual (2002) & & & & & & & & & & $\begin{array}{c}3.027^{* * *} \\
(0.64)\end{array}$ & & \\
\hline \multirow[t]{2}{*}{ Unemployment (2002) } & & & & & & & & & & & $0.767^{* * *}$ & \\
\hline & & & & & & & & & & & $(0.25)$ & \\
\hline Year fixed effects & $\mathrm{Y}$ & $\mathrm{Y}$ & $\mathrm{Y}$ & $\mathrm{Y}$ & $\mathrm{Y}$ & $\mathrm{Y}$ & $\mathrm{Y}$ & $\mathrm{Y}$ & $\mathrm{Y}$ & $\mathrm{Y}$ & $\mathrm{Y}$ & $\mathrm{Y}$ \\
\hline MAN area fixed effects & $\mathrm{Y}$ & $\mathrm{Y}$ & $\mathrm{Y}$ & $\mathrm{Y}$ & $\mathrm{Y}$ & $\mathrm{Y}$ & $\mathrm{Y}$ & $\mathrm{Y}$ & $\mathrm{Y}$ & $\mathrm{Y}$ & $\mathrm{Y}$ & $\mathrm{Y}$ \\
\hline
\end{tabular}

Notes: Results from alternative specifications. Dublin City omitted. All explanatory variables lagged by one period, with exception of two period lads as indicated. Zero-inflated models consist of a logit first-stage and count second-stage. Only second-stage reported, identical variable set used in both stages. ${ }^{* *} \mathrm{p}<0.01,{ }^{* *} \mathrm{p}<0.05,{ }^{*} \mathrm{p}<0.1$. 
Table B2: Moran's I calculation for model residuals

\begin{tabular}{|c|c|c|c|c|c|c|c|}
\hline Model & Year & Moran's I & p-value & Model & Year & Moran's I & $\mathrm{p}$-value \\
\hline \multirow[t]{10}{*}{ FDI } & 2002 & $0.0227^{*}$ & 0.081 & \multirow[t]{10}{*}{ High tech } & 2002 & 0.0003 & 0.274 \\
\hline & 2003 & $0.0197^{*}$ & 0.099 & & 2003 & 0.0046 & 0.273 \\
\hline & 2004 & -0.0101 & 0.444 & & 2004 & -0.0046 & 0.342 \\
\hline & 2005 & -0.0077 & 0.478 & & 2005 & -0.0074 & 0.487 \\
\hline & 2006 & -0.0092 & 0.477 & & 2006 & -0.0058 & 0.392 \\
\hline & 2007 & -0.0124 & 0.392 & & 2007 & -0.0073 & 0.429 \\
\hline & 2008 & -0.0076 & 0.46 & & 2008 & -0.0085 & 0.477 \\
\hline & 2009 & -0.0124 & 0.396 & & 2009 & -0.0094 & 0.459 \\
\hline & 2010 & -0.006 & 0.418 & & 2010 & -0.0072 & 0.435 \\
\hline & 2011 & -0.0076 & 0.426 & & 2011 & -0.0093 & 0.439 \\
\hline \multirow[t]{10}{*}{ Domestic } & 2002 & -0.0084 & 0.48 & \multirow[t]{10}{*}{ Low tech } & 2002 & -0.0121 & 0.313 \\
\hline & 2003 & -0.0078 & 0.484 & & 2003 & -0.0109 & 0.371 \\
\hline & 2004 & -0.008 & 0.482 & & 2004 & -0.0085 & 0.485 \\
\hline & 2005 & -0.0081 & 0.398 & & 2005 & -0.0085 & 0.441 \\
\hline & 2006 & -0.0077 & 0.466 & & 2006 & -0.0071 & 0.492 \\
\hline & 2007 & -0.0076 & 0.443 & & 2007 & -0.0084 & 0.487 \\
\hline & 2008 & -0.0073 & 0.486 & & 2008 & -0.0094 & 0.364 \\
\hline & 2009 & -0.0076 & 0.485 & & 2009 & -0.103 & 0.353 \\
\hline & 2010 & -0.0077 & 0.477 & & 2010 & -0.0097 & 0.428 \\
\hline & 2011 & -0.0074 & 0.424 & & 2011 & -0.0102 & 0.304 \\
\hline
\end{tabular}

\section{References}

Lyons, S. (2014). Timing and determinants of local residential broadband adoption: Evidence from Ireland. Empirical Economics, 47(4):1341-1363. 